Wacana Vol. 22 No. 2 (2021): 253-294

\title{
From dugouts to double outriggers Lexical insights into the development of Swahili nautical technology
}

\author{
MARTIN WALSH
}

\begin{abstract}
${ }^{1}$
The early history of nautical technology in the western Indian Ocean and adjoining parts of the African coast is poorly understood. In the absence of evidence from shipwrecks, it has hitherto been based largely on the uncertain interpretation of a few documentary references and speculation surrounding technological parallels and assumed lexical resemblances. This article examines some of the linguistic evidence in a more rigorous way, by undertaking a crossdialectal comparison of names for watercraft and terms for outriggers in Swahili (Kiswahili), a Bantu language spoken on the islands and in scattered communities along the western seaboard of the Indian Ocean. The resulting analysis provides a new outline of the development of Swahili nautical technology and maritime culture, highlighting the key role played by particular boat forms, and the relative importance of indigenous innovation and different external influences, including the elusive impacts of Austronesian seafaring.

KEYWORDS

Nautical history; western Indian Ocean; Swahili; maritime culture; historical linguistics.

${ }^{1}$ I am especially grateful to Tom Hoogervorst and Sander Adelaar for their invaluable comments on some of my etymological proposals and many other good suggestions, and also to Claude Allibert, Pierre-Yves Manguin, and Pedro Pinto for responding to my queries and sending related publications. The usual disclaimer applies.
\end{abstract}

MARTIN WALSH is an Adjunct Professor in the School of Business Studies and Humanities at the Nelson Mandela African Institution of Science and Technology (NM-AIST) in Arusha, Tanzania, and a Research Affiliate of the Sheffield Institute for International Development (SIID) in the University of Sheffield, UK. When not working as a freelance consultant, he writes about different aspects of history, language, and society, mostly in eastern Africa. He was the founding editor of the online Oxfam Research Guidelines and is the Book Reviews Editor of Tanzanian Affairs, the bulletin of the Britain-Tanzania Society. His most recent papers have included a review of the literature on the role of pangolins in myth and ritual in Africa and Asia, and the latest in a series of joint studies with Helle Goldman of endangered (and extinct) wildlife and conservation conflicts in Zanzibar. Martin Walsh can be reached at: martin.walsh@cantab.net. 


\section{INTRODUCTION}

This article presents initial findings from a comparative linguistic study of cultural history and people's interactions with the environment in the western Indian Ocean and adjoining coastlands of the African continent. It draws its inspiration from Waruno Mahdi's pioneering work on the early history of Austronesian (and preAustronesian) seafaring and cultural contacts across the Bay of Bengal and beyond (1998, 1999a, 1999b, 2016, 2017), as well as his forensic analysis of Austronesian etymologies in other publications (including his 1994a, 1994b, 2007). It also picks up on related research on the history of maritime technology in the Indian Ocean, which has expanded the historical and geographical scope of investigation, while similarly combining evidence from multiple sources, including historical linguistics and the ethnographic study of material culture (see, for example, D.A. Agius 2002, 2005, 2008; A. Al-Salimi and E. Staples 2017; S. Chandra and H.P. Ray 2013; T. Hoogervorst 2013: 78-100, 2015, 2016; P.-Y. Manguin 2000, 2012, 2016; D. Parkin and R. Barnes 2002).

My own focus in this homage is on the far west of the Austronesian world, on the nautical technology and terminologies of the Swahili people of the East African coast and islands, particularly their names for different boat forms and terms for the various components of outriggers. It is generally assumed that their possession of double outrigger canoes reflects Austronesian influence, although there is no agreement on how exactly the transmission of this technology came about. Researchers have also claimed that they can detect different words of Austronesian origin in Swahili nautical vocabulary as well as in the wider lexicon (see Walsh 2019). In this article, in addition to reviewing the evidence for these claims, I shall also examine alternative etymological proposals, including hypotheses of indigenous origin, and discuss the implications of these for our understanding of the development of nautical technology and maritime culture in the western Indian Ocean.

In addition to known and hypothesized historical connections across the Indian Ocean, there are many other points of comparison between the Swahili and Indonesian worlds and reasons for scholars on either side to look at each other's work. The East African coast and islands share a similar tropical climate with Nusantara and grow many of the same crops, including rice, bananas and a range of other fruits, and tubers which have their origins in the east. They both have complex maritime cultures with long histories of transoceanic trade and migration and deep connections with their coastal hinterlands and inland sources of raw materials and labour. They have both experienced Islamization while retaining significant aspects of pre-Islamic practice and have unifying languages (Swahili; Malay) which reflect this history, not least in their assimilation of loanwords and development as widely spoken lingua franca.

All too often, colonial historiography on both sides of the Indian Ocean overemphasized external "civilizing" forces and overlooked the significance of "local genius". One consequence of this on the Swahili coast is that popular accounts of history and language continue to reproduce "Orientalist" tropes. 
Local linguistic variation remains under-researched and the potential for cross-dialectal comparison has generally been overlooked. Yet, as I hope this paper will demonstrate, these are critical to reconstructing the region's past and evaluating hypotheses about cultural and linguistic transfers across the Indian Ocean and the important role played by indigenous innovation and adaptation.

\section{LINGUISTIC BACKGROUND AND METHODOLOGY}

Swahili (Kiswahili) is a Bantu language belonging to the wider Niger-Congo language family. It is generally classified as a member of the Sabaki branch of Northeast Coast Bantu (NECB), one of the well-defined constituent groups of Eastern Bantu. Figure 1 shows the position of Swahili in the genetic classification of the Sabaki languages as posited by Derek Nurse and Tom Hinnebusch in their Swahili and Sabaki; A linguistic history (1993), the standard study and only detailed reconstruction of this group. Together with Nurse's earlier work (D. Nurse 1982, 1984/85; D. Nurse and T. Spear 1985), it is also the source of the classification of the primary dialects of Swahili which is shown in Figure 2 and that I have outlined elsewhere (Walsh 2018). As we shall see, the split between the northern and southern dialects is particularly important. It is based on the analysis of phonological, lexical, and morphological isoglosses, including the sound correspondences shown in Table 1, which shows the southern dialects as the more conservative.

\begin{tabular}{|c|c|c|c|}
\hline Proto-Sabaki & ND & SD & Exceptions \\
\hline${ }^{*} \mathrm{C}$ & $\underline{\underline{t}}$ & $\check{c}$ (ch) & \\
\hline *nc & $\underline{\underline{t}}^{\mathrm{h}}$ & $\check{\mathrm{c}}^{\mathrm{h}}$ & Mwiini (ND) nt \\
\hline *nj & $\mathrm{nd}$ & nj & Chifundi (ND) nj $\sim$ nd \\
\hline$* j$ & $\check{\mathrm{z}} \sim \mathrm{y} \sim \varnothing$ & $\dot{j}$ & $\begin{array}{l}\text { Mombasa dialects (ND) and } \\
\text { Chifundi (ND) behave like SD }\end{array}$ \\
\hline *W/_[-round] & $v$ & $\mathrm{w}$ & $\begin{array}{l}\text { Mwiini (ND) w, Bajuni (ND) v, } \\
\text { Chifundi (ND) w }\end{array}$ \\
\hline${ }^{*} \mathrm{k}<* \mathrm{k} /{ }_{-}^{*} \mathrm{i}$ & š (sh) & $\mathrm{s}$ & Bajuni (ND) s, Unguja (SD) š \\
\hline${ }^{*} \mathrm{~g}$ & $\varnothing \sim g$ & $\mathrm{~g}$ & Mwiini (ND) g \\
\hline
\end{tabular}

Table 1. Principal sound correspondences differentiating between northern and southern dialects of Swahili (ND vs. SD) (after Nurse and Hinnebusch 1993). ${ }^{2}$

${ }^{2}$ Proto-Sabaki ${ }^{*} \mathrm{~W}$ is reconstructed as a labial approximant, / $\mathrm{v} /$ is a labiodental approximant. Note that, whereas I have cited Nurse and Hinnebusch's reconstructions using their phonemic transcription, elsewhere I have used the orthographic conventions of Standard Swahili, while also underlining dental / $\underline{t} /$ and $/ \underline{d} /$, and showing aspiration with raised $/ \mathrm{h} /$. These phonemic distinctions are not always marked in the sources. 


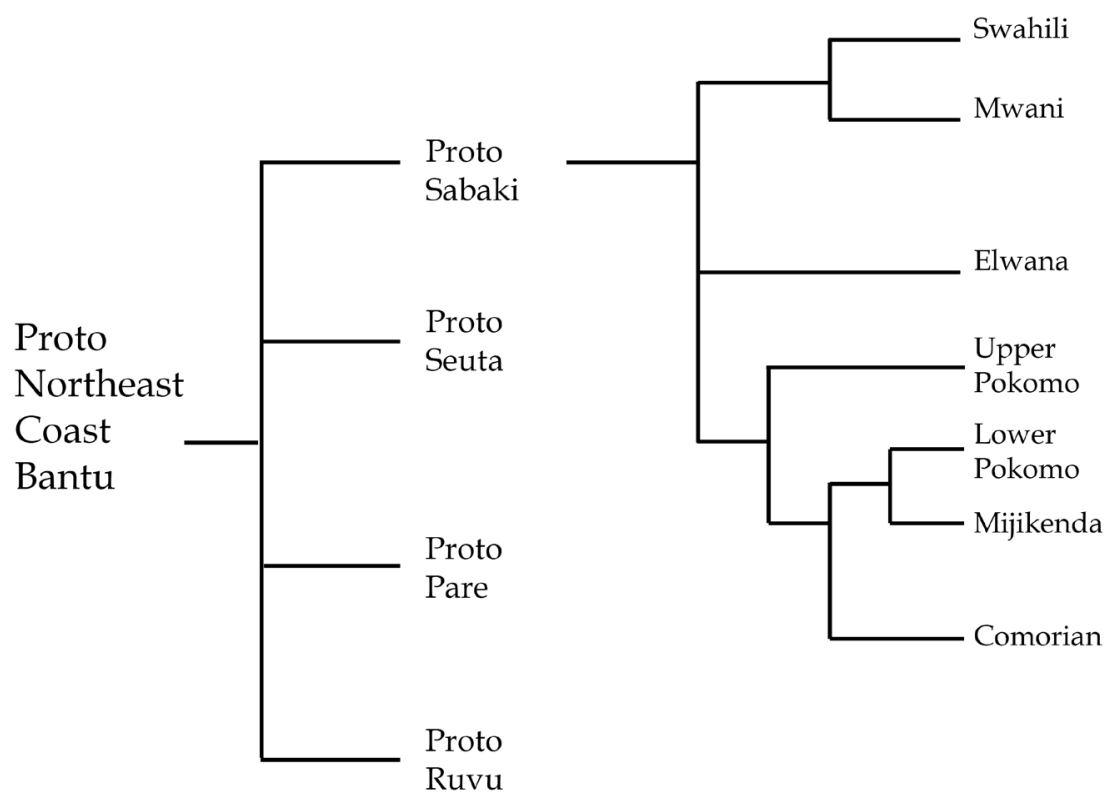

Figure 1. Genetic classification of the Sabaki languages (after Nurse and Hinnebusch 1993).

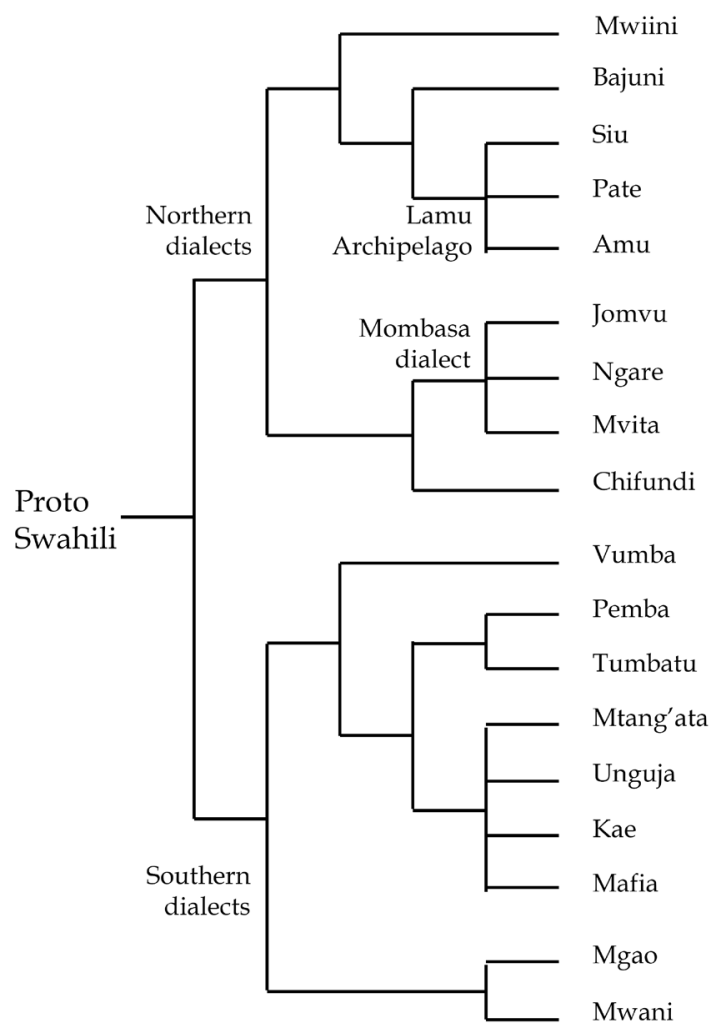

Figure 2. Classification of Swahili dialects (after Nurse 1984/85, Nurse and Spear 1985; Nurse and Hinnebusch 1993). 
It is important to note that this is not the only possible interpretation of the north-south split. In a paper published before Nurse and Hinnebusch's (1993) study, Bernd Heine (1989) argued that the northern dialect features present in the Mombasa dialects and Chifundi could be attributed to areal spread rather than inheritance and, consequently, that they should be classified as southern dialects. As far as I am aware, this argument has not been countered or even discussed in the literature and Nurse (2019: 652-656) has continued to treat Mvita and other Mombasa lects as northern dialects which split from the rest before going through the sound and other changes which characterize the core of the group. ${ }^{3}$ This potential reclassification matters because it affects the conclusions which can be drawn from cross-dialectal comparison, and whether terms recorded in Mombasa and elsewhere on the Kenya coast - between Malindi in the north and Chifundi-speaking Mkwiro in the south - can be used as evidence for the reconstruction of Proto-Swahili lexis or that of lower level groups.

Similarly, doubts have also been raised about the inclusion of Mwiini. After considering different possibilities, Nurse and Hinnebusch (1993: 278-281) opted to treat it as the northernmost Swahili dialect. In a subsequent paper, however, Hinnebusch (1996: 76) chose to describe it as a separate language, albeit very closely related to Swahili. Added to the doubts already expressed, this means that only the core group of idioms spoken in and around the Lamu Archipelago - Bajuni, Siu, Pate, and Amu - can be securely identified as northern dialects for the purposes of comparison. I have taken this uncertainty into account in my interpretations of the data discussed below.

Linguistic geography suggests that the Northeast Coast Bantu languages developed as Bantu-speaking farmers spread in a north-easterly direction along the line of the Eastern Arc Mountains in what is now Tanzania and then up the East African coast. Although Nurse and Hinnebusch (1993: 491-493) placed the Sabaki homeland in the far north - to the north of the Tana River, maybe even in southern Somalia - the principle of "least moves" suggests that Proto-Sabaki began to emerge much farther south, perhaps somewhere in northeastern Tanzania where Sabaki's closest relatives can still be found (compare Nurse 2019: 652-654, 663; D. Ray 2014: 26, 77-81). This also fits better with current archaeological evidence, which indicates that eastern Tanzania was being settled by iron-working farmers before the first century BCE, and that they had moved into southeast Kenya by the third century CE - giving us an approximate timeframe for the arrival of Northeast Coast Bantu speakers on the shores of the Indian Ocean and the movement of Sabaki speakers farther north. Swahili might well have been a distinct language by the sixth century, when Unguja Island was being occupied, and the north-south dialect split must have been underway by the time that sites in the Lamu Archipelago

${ }^{3}$ The dialects of Malindi and Mambrui are included on phonological grounds in the same "South ND" group as the Mombasa dialects and tentatively added to the early movers. In earlier classifications they were largely omitted because of their histories of repopulation and resulting "mixed" speech (Nurse and Hinnebusch 1993: 8). Chifundi is not mentioned by name in Nurse (2019) but is included in the early splitting group by implication. 
and on the adjacent mainland were being settled in the eighth century (see S. Wynne-Jones and A. LaViolette 2018 for details). ${ }^{4}$

The early occupation of the Comoro Islands is also generally dated to the eighth century, although it might have begun before. It is not entirely clear who the first occupants were: the strong archaeological signature of Southeast Asian crops suggests that Austronesians, possibly early Malagasy speakers, were there from the start (N. Boivin and A. Crowther 2018). It is important to note that the Bantu settlers were not Swahili speakers, but spoke a rather different Sabaki language, most closely related to the Mijikenda and Lower Pokomo languages of the Kenyan coast. The Bantu Comorian dialects are conventionally classified into two groups, western and eastern. The two western dialects, Ngazidja and Mwali, are spoken on Grand Comore and Mohéli Islands respectively, while the eastern idioms, Ndzuani and Maore, are spoken on Anjouan and Mayotte (Nurse and Hinnebusch 1993: 18-19). Mayotte is also home to two dialects of Malagasy, Kibushi (Kibosy Kimaore) and Kiantalaotsi (Kibosy Kiantalaotsy), speakers of the latter forming a tiny minority (N.J. Gueunier 1986: iii, 1-2).

The linguistic relationship between Malagasy and Comorian is clearly deep-rooted: Malagasy has a significant set of early loanwords from Comorian (O.C. Dahl 1988, 1991; A. Adelaar 2009: 726-727), while all the Comorian dialects show traces of both Malagasy and Malay influence (Adelaar 2007: 13-15; Nurse and Hinnebusch 1993: 559). Despite a history of contacts and interactions, the direct relationship between Malagasy and Swahili seems to have been rather more one-sided, with Malagasy containing many Swahili loanwords (Adelaar 2009: 727-728), whereas Malagasy loanwords in Swahili appear to be few and far between (Nurse and Hinnebusch 1993: 332, 559). It is important to add here that most attempts to identify words of Austronesian origin in Swahili have been ad hoc and unsystematic, with potential loanwords plucked at random from dictionaries and other sources and relatively little attention paid to the regularity of sound correspondences or the need to explain cases of divergence. Some of the loanwords which have been identified have evidently entered Swahili via other languages, including Arabic (see, for example, the proposed loanwords in B. Krumm 1940 and J.K. Teubner 1974). Other proposals have turned out to be based on chance resemblance, a fate which has befallen some of my own earlier proposals (Walsh 2017, 2019), including a number published by other researchers (R. Blench 2012; Hoogervorst 2013).

In order to avoid a repeat of the same problems, the present study attempts to adhere to the strictures outlined by Adelaar (2016: 94) in his own recent critique of the unsystematic use of loanwords as evidence. This includes limiting investigation to a relatively restricted context and well-defined lexical fields in which evidence of early borrowing might be anticipated. As far as the available sources allow, I have examined the distribution of lexical items

\footnotetext{
${ }^{4}$ These dates for the development of Swahili are earlier than those proposed by Nurse and Spear (1985), reflecting subsequent developments in archaeological research and dating.
} 
in the different dialects of Swahili and related languages, not least because this allows for the generation of hypotheses about the comparative dating of borrowing and innovation. This is simply not possible when only Standard Swahili is used. All the dates given in this paper should be understood as provisional and open to revision. However, whereas comparative linguistic analysis can only give us relative dating, broad correlations between linguistic and archaeological data do at least give us estimated timelines that can be refined as research progresses.

\section{WATERCRAFT AND THEIR NAMES}

In their paper "When did the Swahili become maritime?", J. Fleisher et al. (2015: 100-101) argue that "despite their proximity to and use of the sea, the level of maritimity in Swahili society increased greatly over time": "Although the ancestors of the contemporary Swahili [...] began living on the coast in the mid-first millennium C.E., we suggest that in practice they should be considered 'maritime' only after circa C.E. 1000". This argument has been severely criticized, not least for its restricted definition of maritimity, over-emphasis on external influences rather than indigenous African innovation, and consequently its implied reproduction of discredited orientalist tropes about the nature of Swahili society and culture (E.B. Ichumbaki 2017; C.M. Kusimba and J.R. Walz 2018). A more nuanced view of the development of pre- and early Swahili maritime adaptations is presented by A. Crowther et al. (2016), although their focus is on a single site, and like most other students of East African coastal history they have relatively little to say about the spread of Swahili-speaking communities along the whole length of the coast, a spectacular expansion which must have required the use of boats.

Perhaps not surprisingly, most of the literature on Swahili maritime culture deals with their engagement in Indian Ocean trade in the era of globalization that began when the Portuguese first rounded the Cape of Good Hope (for example, E. Gilbert 2004; J.H.A. Jewell 1969; E.B. Martin and C.P. Martin 1978; A.H.J. Prins 1965; A. Sheriff 2010; A. Villiers 2006). As Fleisher et al. (2015: 106) observed, "Studies of the mtepe, the iconic Swahili sewn ship [sic], are mostly based on 19th- and early 20th-century evidence [...], and few studies have tackled earlier Swahili maritime technology and navigation". There is also an absence of archaeological evidence in the form of wrecks and very few documentary references to local watercraft from the period before the sixteenth century. The early history of Swahili maritime culture and nautical technology has yet to be written. My focus is therefore primarily on the boats and technologies which predate the modern era or have been the subject of historical speculation relating to earlier times, including claims of direct or indirect Austronesian influence.

When Northeast Coast Bantu speakers first reached the Indian Ocean, they were familiar with the use of dugout canoes on rivers and must have encountered more developed craft being used by visiting traders, if not by fishers and foragers already living on the coast and nearby islands. The Periplus 
of the Erythraean Sea, thought to have been written around 40-50 CE, reports that the island of Menuthias (most likely Pemba, Unguja, or perhaps Mafia) "has sewn boats and dugout canoes that are used for fishing and for catching turtles". Moreover, "Two runs beyond this island comes the very last port of trade on the coast of Azania, called Rhapta ['sewn'], a name derived from the aforementioned sewn boats" (L. Casson 1989: 59, 61). The inhabitants of this region, described in Casson's translation as "Very big-bodied men, tillers of the soil" (1989: 61), might have been Bantu-speaking farmers, although perhaps not Northeast Coast Bantu, if Rhapta was located in the Rufiji Delta or farther south as some scholars suspect. We know nothing more about the sewn boats or other local craft of this era. Despite claims to the contrary, there is also no reliable linguistic evidence to indicate that Austronesians were in direct contact with the East African coast at this time, including the period when Proto-Sabaki was being formed.

As might be expected, none of the Proto-Northeast Coast Bantu lexical innovations proposed by Nurse and Hinnebusch (1993: 288-289) implies knowledge of the sea. ${ }^{5}$ By contrast, their Proto-Sabaki reconstructions include a number of innovations and loanwords which refer to marine resources or appear to have been borrowed from Arabic, Farsi (Persian), or an Indian language (1993: 290-292, 316-317), suggesting that Sabaki speakers were living close to the Indian Ocean and were familiar with its products at an early stage in the evolution of the language group. ${ }^{6}$ Only two terms for watercraft, however, were reconstructed by Nurse and Hinnebusch. One was the inherited Bantu word *kyombo 7/8 "vessel, tool" (1993: 635), reflexes of which, including Standard Swahili chombo 7/8 (plural vyombo), denote vessels (and utensils) of every kind as well as watercraft. ${ }^{7}$ The second was Proto-Sabaki *Wato 14/6, "canoe", also from a Proto-Bantu root ( ${ }^{*}$-játò BLR3 3252). ${ }^{8}$ The Ilwana (Elwana) reflex has been recorded as waatu 14/6 (Nurse 2000: 230) and its Lower Pokomo equivalents as waho (Nurse and Hinnebusch 1993: 647), and mwau 3/ 4 (mwao by C. Sacleux 1939: 644). ${ }^{9}$ There is no reflex of this word in Swahili.

${ }^{5}$ Terms relating to two crops of Asian origin do appear ("mupunga 3 "rice" and "nkoWo 9 "banana plant, tree"), but even if the semantic reconstructions can be confirmed, the evidence of later loanwords suggests that crops such as these were not introduced directly by Austronesians, at least not initially.

${ }^{6}$ The compilation and analysis of more terms for the coastal environment and marine fauna will likely add to this list of Proto-Sabaki reconstructions, if it can be shown that word roots shared by Swahili and Comorian have not been borrowed by one from the other.

${ }^{7}$ Despite their similar shape and meaning, Swahili chombo 7/8 and the poetic name sambo 9/10 (see below) are not related, as has sometimes been stated or implied (by, for example, J.M. Mugane 2015: 10).

${ }_{8}^{8} \mathrm{~PB}=$ Proto-Bantu; BLR3 = Bantu Lexical Reconstructions 3 (Y. Bastin and T. Schadeberg 2005), followed by the ID number of the reconstruction cited.

${ }^{9}$ Ilwana retains all seven Proto-Sabaki vowels; I have changed Nurse's (2000) transcription to match that of Nurse and Hinnebusch (1993). Lower Pokomo mwau can be found in online media reports about the Tana River; Sacleux compared it to Swahili mwao 3/4, referring to pieces of wood used as support, including boards placed at the bottom of a boat, which he derives from the verb -alia, "place small pieces of wood side by side in the bottom of a pot, to prevent the contents from burning" (1993: 52-53). 
The general name for a canoe in Swahili (mtumbwi 3/4 in Standard) is a lexical innovation shared with and presumably borrowed by neighbouring Seuta and Ruvu languages. ${ }^{10}$ Nurse and Hinnebusch reconstruct Proto-Swahili "mutumbwi 3/4 "canoe", deriving it from the Proto-Sabaki verb *tumb- "to swell" and its reversive form *-tumbul- "to cut open", and so a reference to the carving and hollowing out of the log. Indeed, dictionary definitions and ethnographic descriptions refer primarily to dugouts made from a single tree trunk, and emphasize that the name is never used to denote canoes with outriggers. As Prins (1967: 54) notes, however, modern dugouts can be composite, with separate stem/prow and stern pieces attached, as well as sails and rudders. They can reach more than six metres in length and the most seaworthy ones can be used for trolling as well as line fishing.

Nurse and Hinnebusch (1993: 295) also list a second canoe name as an innovation in Proto-Swahili, in this case making clear that it was borrowed. The hori 5/ 6 (plural mahori) is a ship's boat and passenger canoe (Prins 1970: 12), the Swahili name of which scholars have derived from a variety of south Asian languages (see A.Y. Lodhi 2000: 168-169). The Arabic hüri is described by Agius (2002: 119) as "[p]erhaps the most common of primitive dug-outs used in many parts of the Gulf, the Arabian Sea and the Red Sea [...] made of mango from the Malabar coast and imported from Bombay and Calicut ready hollowed". He adds that the name is borrowed from Hindi, from a Sanskrit original (2002: 121, 2008: 123; see also J. Quadros 1938: 138; T. Vosmer 2017: 194). Nurse and Hinnebusch emphasize the difficulty of dating hori and similar loanwords containing phonemes which have remained stable over time: "It is simply not possible to say linguistically whether these entered Swahili/Sabaki 300 or even 1,300 years ago" (1993: 318). Also given a lack of local dialect attestations, I find their tentative reconstruction of Proto-Swahili *(i)hori unconvincing. This is a loanword that might well have entered Swahili much more recently, along with most lexical transfers from around the Arabian Sea, nautical vocabulary included.

The etymologies of these and other Swahili names for watercraft are summarized in Table 2. This includes other recorded names for dugouts and small canoes: kigusa (BAKIZA 2012b: 51), kiperea (H.K. Binns 1925: 98; L. Krapf 1882: 153; Sacleux 1939: 395), mbirimiti (Sacleux 1939: 527), mjoo (Prins 1970: 24; Sacleux 1939: 541), and muchoro/nchoo (A. Kipacha 2004: 197; Sacleux 1939: 668; T.C. Schadeberg and F.U. Mucanheia 2000: 258). Relatively little is known about these different local craft, and none of their names can be reconstructed to Proto-Swahili on the evidence currently available. They all appear to have originated after the split between the northern and southern Swahili dialects, some probably much more recently.

\footnotetext{
${ }^{10}$ It also turns up as ishimunumbwi ishimunyumbwi 7/8, with two fossilized prefixes, in the Southern Highlands language Sangu (Walsh 1985).
} 


\section{Type of watercraft}

Dialect - name of craft - noun class pairing - short definition

(general) chombo, Pemba kyombo 7/8 "boat (generic)" (also "vessel, tool, utensil ...")

Bajuni muchumbwi nchumbwi, Siu mchumbwi, Mvita, Tumbatu mtumbwi, Pemba ntumbwi 3/4 "dugout canoe"

Mwiini dhalu, Bajuni idau dau 5/6, Mvita, Chifundi/Mkwiro, Kae/Makunduchi, Mafia/Ngome dau 5/6, Tumbatu dalu 5/6 "boat, dhow"

Amu, Mvita shapa 5/6, Jomvu nsapa 3/4 sapa 5/6, Pemba sapa 9/10, Pemba/Kojani sap ${ }^{h}$ 9/6, Kae sapa 5/6 "raft of logs, raffia palm branches, or half a broken boat"

Bajuni mutepe $\sim$ ntepe, Mvita mtepe 3/4 "traditional Bajuni sewn boat"; Tumbatu mtepe 3/4 "dugout canoe"
Etymology

(P)SW = (Proto-)Swahili, ND = northern dialects, SD $=$ southern dialects, $\mathrm{PSA}=$ Proto-Sabaki, $\mathrm{PB}=$ ProtoBantu, BLR3 = Bantu Lexical Reconstructions 3

PSA *kyombo 7/8 "vessel, tool" (Nurse and Hinnebusch 1993: 635) < PB *-jòmbò "thing; utensil" (BLR3 6607).

PSW lexical innovation *mutumbwi 3/4 "canoe", lexical innovation < *tumb- "swell", reversive *-tumbul- "cut open" (Nurse and Hinnebusch 1993: 295, 610) < PB *-tùmb- "swell" (BLR3 3057), *tùmbud- "cut open; pierce" (BLR3 3062).

PSW lexical innovation *idalu 5/6 "large vessel; boat", augmentative of "ndalu 9/10 "waterbailer", originally "strips of young doum palm leaf", which bailing baskets were made from, < PSA *ndala 9/10, "palm frond part", cognate with PSA *mulala 3/4 "dwarf palm" (Nurse and Hinnebusch (1993: 620), = "young doum palm" < PB *-dàdá "palm-tree; palm-frond" (BLR3 799). The boat name has been borrowed back and forth between languages and dialects and it is probably the source of Anglo-Indian "dhow" and related forms.

(P)SW lexical innovation? See also Mvita shapa la nyuki, "honeycomb", literally "raft of bees". Possibly a loanword, though only the Kojani record suggests earlier *sampa, which lacks the final consonant in Malay sampan "flat-bottomed skiff usually propelled by oars, dugout", and might therefore be a chance resemblance. (See Hoogervorst 2013: 85-86 for the etymology of sampan and its possible connection to the sambook. Also, sambo sambu below).

ND lexical innovation. Compare Bajuni itepe tepe 5/6 "broad base of the petiole of the coconut palm" < PSA *-chepula "sprout anew" (Nurse and Hinnebusch 1993: 582). Nurse and Hinnebusch (1993: 295) propose PSW *muTepe 3/4 "type of sailing vessel", possibly from PB *-tèp- "bend; sway, swing" (BLR3 2864), but this is unlikely and SD attestations are evidently loanwords from ND. 
Bajuni mbirimiti 9/10 "small canoe", literally "two trees"

Bajuni, Mvita kiperea 7/8 “small canoe"

Bajuni mjoo njoo, Mvita mjoo 3/4 "dugout canoe"

Bajuni muchoro $~$ nchoro, Mafia/Ngome nchoo 3/4, Koti nttoro 5/6 "dugout canoe"

Tumbatu kigusa 7/8 "dugout canoe"

(general) hori 5/6, "ship's boat, passenger canoe"
ND lexical innovation < mbiri "two" + mti 3/4 "tree": mbiri < PSA *-Wili "two" (Nurse and Hinnebusch 1993: 650) < PB *-bidí "two" (BLR3 190); mti < PSA *muti 3/4 "tree" (Nurse and Hinnebusch 1993: 621) < PB *-tí 3/4 "tree; stick" (BLR3 2881). This is a loanword in Bajuni (which has mbili and nchi 3/4) and its source might be a neighbouring Sabaki language.

ND lexical innovation, possibly < Mvita, SD -pwelea "run aground" < PSA *-pw- "ebb" (Nurse and Hinnebusch 1993: 606) < PB *-pó"dry up" (BLR3 7160).

ND lexical innovation < mjoo 3/4, "tree species (unidentified)": used to make the dugout; this tree is also called mjoja in Mvita. The etymology of both tree names is unknown.

SD lexical innovation, probably <-chora, "carve, draw" < PSA ?*-cor- "carve, draw" (Nurse and Hinnebusch 1993: 490, 660), possibly from a Cushitic source. The Bajuni definition specifies that these dugouts are made by the people of the Rufiji Delta, the most important source of mangrove poles on the coast.

SD lexical innovation, compare Mrima kigusamaji 7/8 "dragonfly", literally "touches the water" < SD -gusa "touch" + maji 6 "water": -gusa loanword from a Seuta or Ruvu language (Nurse and Hinnebusch 1993: 302) < PB *-kúc"rub; wash" (BLR3 1990); maji < PSA *maji 6 "water" (Nurse and Hinnebusch 1993: 631) $<$ PB *-jîji 6 "water" (BLR3 3433).

loanword < Arabic hūri < Hindi hōri $<$ Sanskrit hoda (Agius 2002:121). Nurse and Hinnebusch (1993: 295) tentatively suggest PSW *(i)hori 5/6 "kind of canoe", but this is unlikely, and they themselves underline the difficulty of dating loanwords such as this (1993: 318). 
Ngozi (poetic) sambo sambu 9/10 loanword, probably < Malagasy sambo, "boat (generic)" "boat, vessel" < Old Malay sāmvaw, "vessel" (Adelaar 1994: 54). Compare also sambuku 9/10 "transom vessel" < Arabic sānbuk (and variants) "sambook, a kind of sailing boat" (Agius 2002: 83-86). H. Yule and A.C. Burnell (1903: 788) suggest a link between the latter and Sanskrit śambūka "a bivalve shell", but this derivation reminiscent of the etymologies of chombo and dau (see above) - is doubted by Hoogervorst (2013: 85).

Mwiini chingalaawa 7/8, Bajuni, Chifundi ngalawa, Mvita ngalawa ngarawa 9/10 "outrigger canoe"; Mwani ngalawa 9/10 "sailing boat"

loanword from the interrelated series of terms which includes Anglo-Indian gallevat "galley" (Yule and Burnell 1903: 361), Marathi galbat "ship" (J.T. Molesworth 1857: 129), Farsi galbat "large boat or ship" (F.J. Steingass 1892: 1093), and possibly earlier Arabic jalba (plural jilāb or jalbāt) "light passenger boat" (Agius 2002: 93-96).

Table 2. Names of Swahili watercraft and their etymologies (for further details see main text).

In addition to the dugout term which was a Proto-Swahili innovation $\left({ }^{*}\right.$ mutumbwi), there is at least one other name which can be reconstructed to an early stage in the development of Swahili. This is the boat which is called dau 5/6 (plural madau) in Standard Swahili. This is one of the most widely used Swahili names, with different types being named by a change of prefix - like diminutive kidau 7/8 (plural vidau) ${ }^{11}$ - or the addition of a qualifier, such as dau la mataruma, "with ribs", for the commonest kind of plank-built fishing-boat, and dau la msumari, "with nail(s)", for the larger keeled dhows (Prins 1967: 54, 1970: 7). These are proper sailing-craft which now carry large lateen sails, although this was not always the case: the dau la mtepe (see below) carried a square sail of matting, and other kinds of sewn dau might once have done so too. Unlike the mtumbwi and other kinds of dugout canoe, the hull of the Swahili dau is constructed solely of boards/planks and other pieces of cut and carved wood.

The origin of the name dau has hitherto bamboozled researchers; Nurse and Hinnebusch (1993) did not mention it all, even in their lists of lexical innovations. At first sight it looks like a loanword, but has also been proposed as the source of the word "dhow", "a collective usage by English speakers to represent any Perso-Arab or Indian or east African vessel" (Agius 2002: 33; see also Yule and Burnell 1903: 314-315). Despite determined efforts to prove that

\footnotetext{
${ }^{11}$ Note also the unusual Chifundi diminutive, chichidau 7/8 (recorded in Mkwiro on Wasini island: Walsh 1986: 2), with a reduplicated prefix like that of the dialect name itself, Chichifundi (H.E. Lambert 1958b: 7-9).
} 
the Swahili word is borrowed (Agius 2002: 34-35, 58-61; F. Johnson 1939: 71; Krumm 1940: 119; Sacleux 1939: 165; TUKI 2001: 55), cross-dialectal comparison makes it clear that it must derive from earlier Swahili *idalu, hence the reflexes with /1/ in widely separated dialects (Mwiini dhalu and Tumbatu dalu) as well as older records of one of the Mijikenda dialects (Rabai) and three of the Seuta languages of northeastern Tanzania (BAKIZA 2012b: 22; F. Gleiss 1912: 59; W.H. Kisbey 1906: 7; C.W. Kisseberth and M.I. Abasheikh 2004: 86; L. Krapf and J. Rebmann 1887: 33; H.W. Woodward 1882: 69). ${ }^{12}$ This form was probably also the source of the following records from the late eighteenth century: "In the 1780s, correspondence from the Mozambique captaincy [...] evoked 'dallos' belonging to Swahili merchants. A few French sources also mention local "dalles'" (T. Vernet 2015: 173). It seems that this word was transferred back and forth between different languages and dialects on the coast, hence the occurrence of intervocalic /1/ in Swahili dialects which might otherwise be expected to have lost it by now. ${ }^{13}$

The earlier history of this name can be deduced from the existence of a cognate term, ndau 9/10, recorded in Bajuni, Mvita, and Standard Swahili dictionaries with the meaning "water-bailer", a basket or ladle used to scoop up and dispose of excess water in the holds/bilges of boats (F. Burt 1910: 200; Johnson 1939: 331; C.J.W. Lydekker 1919: 91; Prins 1970: 29; Sacleux 1939: 669; W.E. Taylor 1891: 29-30; TUKI 1981: 210, 2001: 240). ${ }^{14}$ If we reconstruct earlier *ndalu 9/10, it is apparent that *idalu 5/6 is its augmentative counterpart, and we can hypothesize that the larger vessel derived its name from the smaller one designed to keep it afloat. ${ }^{15}$ The use of water-bailers was critical in sewn boats, as different observers remarked about the leaky mtepe (Gilbert 2018: 382; J. Hornell 1941: 62; Taylor 1891: 34). Lydekker (1919: 91) observed that "[t]wo of the crew bale together, one man standing above the other in the hold, and pass to one another a kind of basket, known as ndao". Hornell (1941: 62) was told that "[t]his bailer was a bowl-shaped basket of closely woven palmleaf strips, with a wooden handle across the circular mouth. It was about 24 inches in diameter and 9 inches deep". The name of the bailer - ndau and ndao

${ }^{12}$ It also seems to have found its way farther inland, for example, into the Central Kenya Bantu languages Gikuyu (itarũ 5/6, "boat, ship, pontoon, ferry, raft, canoe", T.G. Benson 1964: 434) and Kamba (italũ 5/6, "a cableway over a stream; a row boat; canoe", Africa Inland Mission 1970: 25).

13 *l-loss is a relatively late sound change in Swahili: written sources suggest that it was ongoing throughout the eighteenth century (Nurse and Hinnebusch 1993: 104).

${ }^{14}$ Note also a second meaning which Sacleux registered for dau 5/6: "Coco de mer cut into the shape of a small boat (nacelle)" (1939: 165). The coco de mer or sea coconut is the once muchmythologized fruit of the double coconut palm, Lodoicea maldivica (J.F.Gmel.) Pers. The palm is endemic to the Seychelles, but its shapely nuts are liable to wash up on beaches around the Indian Ocean and were once prized as rare exotica. According to Sacleux, it was called nazi ya kingazidja 9/10, "the Comorian coconut" (1939: 666), perhaps an indication of from where they were brought or perceived to originate. He does not say what the carved nuts were used for, but use of the augmentative presumably reflects their extraordinary size. J.C. Morgan (1940: 31) recorded the use of bailers made from ordinary coconut shells at Kilwa.

${ }^{15}$ This also recalls the semantic shift that saw Proto-Sabaki *kyombo 7/8, "vessel, tool", become a generic term for boats (see above). 
are alternative spellings which are pronounced the same - must be the same as an Amu dialect term recorded by Sacleux (1939: 669) as ndrao 9/10 "mwaa fibre for plaiting". Northern dialect mwaa (Standard Swahili mnyaa) $3 / 4$ is the doum palm, Hyphaene spp., strips of which were also used in caulking the mtepe (see below). They were presumably also used to weave bailing baskets, and this led to an extension of the original meaning of the word. On the basis of the attestations in Mvita (ndaa) and the two Eastern Comorian dialects (ndrala), Nurse and Hinnebusch (1993: 620) reconstructed Proto-Sabaki *ndala 9/10, "palm frond part", cognate with Proto-Sabaki *mulala 3/4 "dwarf palm" (< PB *-dàdá, BLR3 799), a reference to the young doum palms from which leaf strips for plaiting are taken. ${ }^{16}$

The Swahili dau, originally *idalu, was therefore named after waterbailers (Proto-Swahili *ndalu) which were woven from leaf strips (< ProtoSabaki *ndala) taken from the young doum palm (Proto-Sabaki *mulala). This etymology supports the conjecture that the original *idalu was a sewn boat, as Prins (1967: 54) surmised from the fact that nail-built boats were given their own name, dau la msumari. It also provides us with an important insight into early Swahili history, suggesting that their spectacular expansion along the coast of eastern Africa was made possible by their ability to make and sail their own relatively sophisticated and robust sewn boats. Furthermore, it is likely that Hornell (1941: 54, 1942: 27) was right when he asserted that the Swahili name was the source of Anglo-Indian "dhow" and the same must go for the series of related names, which include Arabic and Farsi dāw "slave and trading vessel" (Agius 2002:34) and Indian counterparts like Gujarati ḍāu and Marathi $d \bar{a} v$, which likewise appear to be loanwords. ${ }^{17}$

Much has been made in the literature of the sewn boats which survived into the twentieth century and are called mtepe 3/4 (plural mitepe) in Standard Swahili (N. Chittick 1980; V.L. Grottanelli 1955: 195-197, 340-343; G.W. Hatchell 1961; Hornell 1941, 1942; Lydekker 1919; E.B. Martin and C.P. Martin 1978: 94-96; P. Poumailloux 1999; Prins 1959, 1965: 82-84, 1982; P.D. Sentance 1981; Sheriff et al. 2006). Prins (1970: 26) described this as a "sewn boat of up to 30 tons, double ended and with upright mast, hoisting a square matting sail". Some late examples were much larger than this (Gilbert 1998: 46), while a smaller, modified version known as the dau la mtepe was also built (Prins 1959: 210). Ever since Richard F. Burton (1872 I: 73) described the mtepe as the "lineal descendant" of the sewn boats of Rhapta, researchers have waxed

\footnotetext{
${ }^{16}$ This chain of connections has been missed by earlier researchers. One reason for this is that Sacleux (1939: 669) equated Ngazidja ndau 9/10, "bucket", with Swahili ndoo 9/10 "bucket" (see also Sacleux 1979: 224), adding Mvita ndau 9/10, "scoop" to the same entry in his dictionary. Nurse and Hinnebusch (1993: 598) compounded his mistake by including Ngazidja ndrau as one of the regular reflexes of Proto-Sabaki *ndoWo 9/10 "container for liquid, pail, bucket", cognate with PSA *-loW- "become wet, soaked" < PB *-dob- "be wet" (BLR3 1086). The Ngazidja word, which is not recorded in other Comorian dialects, or indeed other dictionaries of Ngazidja, should instead have been interpreted as a reflex of earlier *ndalu and as a loanword from Swahili (either before or after the loss of ${ }^{*}$ ).

${ }^{17} \mathrm{My}$ thanks to Tom Hoogervorst for this observation and supplying the Gujarati and Marathi terms (personal communication, 29-3-2020).
} 
lyrical about its ancient pedigree, despite the caution shown by some. Nurse and Hinnebusch (1993: 295) reconstructed *mutepe 3/4 as a Proto-Swahili lexical innovation, but had scant evidence for this. It seems instead to have been a much later northern dialect innovation, which might well have arisen in Bajuni, although this precise origin cannot be proven on the basis of the linguistic evidence alone. The earliest mention of the name ("mutepis") is in a Portuguese description of ships from the Lamu Archipelago written in 1661 (Vernet 2015: 173, 194). Later sources agree that it was a "Gunya" or Bajuni craft, and that " $[\mathrm{t}]$ he chief, and indeed almost the sole locality where the mtepe and its successor, the dáu [la mtepe] were built, was Faza, a town on Pate or Patta Island in the Lamu archipelago" (Hornell 1941: 55). According to Prins (1959: 211), records suggested that they "were mainly engaged in traffic between Zanzibar and the Lamu Islands, and that the crews were exclusively Bajun". They were particularly well suited to coastal trading and working in the shallow water of creeks, in which the collection of mangrove poles was one of their principal occupations (Gilbert 1998: 46-48).

Various etymologies have been proposed for mtepe, which in the Bajuni dialect is pronounced mutepe or ntepe 3/4, with dental / / / (Sacleux 1939: 610, 884). The list of suggested "oriental" sources ranges from (supposed) Arabic "mtafieh" (Prins 1982: 88)18 to Tamil mitappu, "floating; boat, ship, raft, float of a fishing line" - to give just some of its meanings (C. Allibert 1984: 190, 2012: 350; T. Burrow and M.B. Emeneau 1984: 431; Poumailloux 1999: 294). The Tamil and related Dravidian candidates have been compared to Sanskrit tarpa-, talpa-, Prakrit tappa- "raft, float", and even the trappaga of the Periplus, galleys used by local fishermen in the Gulf of Cambay on the Arabian Sea coast of India (Burrow and Emeneau 1984: 299, 431; Casson 1989: 79, 203). None, however, is a good phonological and/or semantic fit with Bajuni mutepe. The only lesson, perhaps, that can be drawn from this is that there are so many named boat types and parts in the Indian Ocean world it is not difficult to find names which superficially resemble one another: much stronger evidence is required to support hypotheses about lexical transfers.

It is also easy to find chance resemblances in Swahili and related languages, especially when important phonological discriminations are ignored. Prins (1959: 212, 1965: 84), citing A. Voeltzkow (1923: 43) on the tendency of old sewn boats to tire and sag, guessed at links to the Swahili verb kutepetea, "to be tired, to sag" and the noun utepe 11/10, "reinforcement along the seam of a sewn cloth", the idea being that the stitching in the hull of the vessel would prevent it from sagging. There are a host of problems with this suggestion, not least that the stem-initial / $t$ / of the verb is alveolar rather than dental, while the unrelated noun is a long-established loanword from English "tape",

18 This word seems to be Prins's invention based on Arabized transcriptions of the Swahili name in Lieutenant J.B. Emery's "Log of H.M.S. Barracouta", written in Mombasa in 1824-1826 and held in Fort Jesus Museum Library (see Vernet 2015: 173, 194). It has been repeated by Poumailloux (1999: 239) and P. Beaujard (2018: 370, 2019 II: 604), who derives it from a root meaning "to float" (see H. Wehr 1979: 658 for the correct spelling of this: țafā, "to float, drift; emerge, rise to the surface; overflow"). 
as the dictionaries make clear (Sacleux 1939: 980; TUKI 2001: 350). It is older than its modern synonym tepu 9/10, "tape" (TUKI 2001: 318), but nowhere near as old as mutepe.

A more likely source for mutepe is another local term, recorded by Sacleux (1939: 308) as ițepe tepe 5/6 (plural matepe) in Bajuni and tepe 5/6 in Amu, "broad base of the petiole of the coconut palm". The petioles or leaf-stalks of the coconut contain a strong white fibre which can be beaten out and made into rough brushes as well as twisted into equally strong cord (I.H. Burkill 1935 I: 612; D.L. Jones 1995: 59). Like most sewn boats in the Indian Ocean, the Bajuni mutepe was sewn with coir, cord made from the fibre of the outer husk of coconuts. ${ }^{19}$ As Hornell (1941: 60-61) described, crushed strips of coconut husk were also used to caulk the mutepe, together with dried strips of the leaf-stalk of the doum palm (see above). Was cord made from the fibrous petioles of the coconut palm, itepe, also used in the sewing or caulking of the mutepe? Was it used in some other way? Or was there a quite different connection between coconut palm petioles and the Bajuni boat? Answers to these questions might have to await the discovery of well-preserved archaeological finds. For now, we may note that itepe has a good Sabaki etymology and can be related to the Proto-Sabaki verb which Nurse and Hinnebusch (1993: 582) reconstructed as *-chepula, "sprout anew" (Standard Swahili and southern dialects have irregular-chipua).

Interestingly, the association with coconut leaves is also present in Comorian cognates of mutepe: Ngazidja mtseve 3/4, "Coconut palm leaves erected to make tight partitions" (F. Fischer 1949: 125), Ndzuani mtseve 3/4, "Coconut leaf with two rows of leaflets braided together on one side" (M. Ahmed-Chamanga 1992: 153), and Maore mutseve 3/4, "Coconut leaf braided in a chevron, for making prayer mats and baskets" (S. Blanchy 1996: 95). These definitions suggest the possibility that *mutepe might originally have referred to an auxiliary structure such as the boat's cabin, with its roof of matting and coconut leaf thatch (Hornell 1941: 67; Lydekker 1919: 90). Again, the evidence is insufficient, and it is possible that the real reason for the naming of the mutepe will remain lost, along with the boat itself.

It would be reasonable to assume that, in addition to dugout canoes ( ${ }^{*}$ mutumbwi) and sewn boats (*idalu), the early Swahili were also familiar with simpler watercraft, such as rafts. Very little has been written, however, about the construction and use of rafts on the East African coast and islands. The Standard dictionaries only give words for floats, chelezo $7 / 8$ (from the verb -elea, "float") and the Portuguese loanword boya 5/6 "buoy" (Johnson 1939: 39, 81).

19 The sewing itself is quite different from the lashed-lug technique of traditional Austronesian boat construction (A. Horridge 1985: 51-54; P.-Y. Manguin 2000: 38). The cord used in Southeast Asian boatbuilding was also distinct. It was usually made from the fibre of Arenga pinnata (Wurmb) Merr., called ijuk in Malay (Manguin 2019: 402). According to (Burkill 1935 I: 234), this is "found in large handfuls about the bases of the petioles, though not of this palm only". When ijuk was not available, other plant fibres were used, including rattan fibre (Manguin 2019: 402), which comes from the stems of different genera of climbing palms (Burkill 1935 II: $1869,1874)$, but is not as strong as sugar palm fibre. 
There is, however, an intriguing dialect term for rafts, attested in Amu and Mvita as shapa 5/6 (plural mashapa) (Binns 1925: 221; Sacleux 1939: 831) and in Jomvu as both nsapa 3/4 (plural misapa) and sapa 5/6 (plural masapa) (Lambert 1958a: 110; W.E. Whiteley 1958: 60). The latter form is also known from some of the southern Swahili dialects in the Zanzibar Archipelago: Sacleux (1939: 794) has sapa 5/6 for the "Hadimu" or Kae dialect of Unguja Island, while the modern dictionary of Pemba dialect terms has sapa 9/10, with an invariant plural (BAKIZA 2012a: 117). Whiteley (1958: 60) recorded $\operatorname{sap}^{h} a 9 / 6$ as the pronunciation in the distinctive fishing community of Kojani Island, off the east coast of Pemba. The possibility that this might derive regularly from a conjectured earlier *sampa, previously led me to suggest a possible connection with Malay sampan and its cognates (Walsh 1995: 17, 2017: 8, 2019). However, the other attestations, without aspiration, do not provide support for this. ${ }^{20}$ Nor do the obvious differences between a raft and the small boats of Southeast Asia (A. Horridge 1986: 47-48), including the sapa of Pulau Ende in East Flores (Horridge 1985: 56, 1986: 43).

While most of the sources refer to the Swahili sapa/shapa as a raft made of logs, Sacleux (1939: 831) also describes its construction from the branches of the raffia palm (mwale 3/4, "Raphia farinifera" (Gaertn.) Hyland), as well as the improvised use of "half of a broken boat". His inclusion of the name under an entry for the Mvita term for a honeycomb, also shapa 5/6, suggests that he thought that the raft was called this by analogy with these flat biological structures, although the reverse could also be argued. If the correspondence between /s/ and / sh/ in variants of the raft's name can be explained, then it might be reconstructed to Proto- or early Swahili. Alternatively, it might be a local innovation, perhaps in one of the Mombasa dialects, which has subsequently spread to others.

A more convincing case can be made for the Austronesian provenance of the poetic (Kingozi) word sambo 9/10 (also recorded as sambu), which is a literary synonym of chombo (< *kyombo) and a generic term for "boat" (Sacleux 1939: 792). It is perhaps best known now from the title of the late Ahmed Sheikh Nabhany's poem about the construction and sailing of a cargo coaster (jahazi 5/6 9/10), Sambo ya Kiwandeo. This was composed in classical utendi metre in 1969-1970 in a composite northern dialect and later translated into English as The Ship of Lamu-Island (A.S. Nabhany 1979). There are, of course, older instances, for example, in one of the aphorisms (No. 180) recorded in Mombasa by the Reverend W.E. Taylor (1891: 40) and in the Shairi la Mnazi, "Song of the Coconut Palm", found by Muhammad Kijuma in an old collection of marriage songs attributed to the culture hero Fumo Liyongo (L. Harries 1952: 159; Mugane 2015: 60). Although sambo is sometimes labelled "archaic", it should be noted that classical Swahili literature does not have the same time depth as, say, Old Javanese: the oldest known translated text in Arabic script dates from the middle of the seventeenth century and most original

${ }^{20}$ It has to be said that aspiration is not always evident to a listener, and in some dialects is being lost under the influence of Standard Swahili pronunciation. 
Swahili works were composed in the eighteenth and nineteenth centuries. Because sambo sambu does not appear in the dialect dictionaries, it cannot be reconstructed to an earlier date.

Taylor, while noting that "sambo is still in use, and is the common word for "ship" in Madagascar" (1891: 40, footnote 2), suggested a derivation from Arabic sānbuk, which describes a family of fishing and other vessels found from the Red Sea westwards and across the Arabian Sea (Agius 2002: 77-86). Sacleux (1939: 792) drew attention to similarities with Malay as well as Arabic; Prins (1970: 33) later wondered whether sambu was short for the borrowed Swahili form sambuku 9/10, "transom vessel from the Red Sea" (1970: 33). As Hoogervorst has shown (2013: 85-86, 2015: 536-538), these terms share a tangled skein of etymological connections across the Indian Ocean which also draws in sampan and related words. Adelaar (1994: 54, 2009: 721-722) has argued persuasively that Malagasy sambo (/sambu/) "boat, vessel", is a pre-migration loanword from Old Malay sāmvaw, "vessel". ${ }^{21}$ Swahili sambo was most likely taken from Malagasy in turn. Given what we know about connections between the Swahili coast and Madagascar in recent centuries - there was even a Swahili-speaking settlement in the northwest of the island - there is no need or justification for ascribing any great antiquity to this borrowing, as has previously been stated or implied (Adelaar 2015: 174; Walsh 2017: 8, 2019). It was probably the result of the same kind of maritime communication which has seen Swahili sambuku adopted in like fashion from Arabic.

\section{OUTRIGGERS AND THEIR TERMINOLOGY}

There is one boat form which I have not discussed so far: the double outrigger. It has long been recognized that the presence of outrigger canoes in the western Indian Ocean reflects Austronesian influence and that this includes some aspects of the design of the ngalawa or double outrigger canoes of the East African coast and islands (A.C. Haddon 1918; Hornell 1934: 318-321; A.M. Jones 1964: 189-192). Some scholars have emphasized the indigenous elements of ngalawa design or argued directly for a local origin (Hatchell 1961: 215; Morgan 1940: 27-28; Prins 1959: 205-210). Linguistic evidence has been adduced to support arguments on both sides, but this has failed to convince, not least because it is largely based on superficial lexical resemblances rather than cross-dialectal comparison and rigorous analysis. In this section, I shall examine the name of the boat and outrigger terminology in the hope of taking this debate forward. This will enable us in turn to advance hypotheses about the source and timing of some of the technological developments and transfers involved.

The summary in Table 2 shows the Swahili dialect variants of ngalawa 9/10, which is the Standard Swahili and most widespread form. I have included the mixed language Koti (Ekoti), spoken on Koti Island and in and around Angoche on the coast of Mozambique. While genetically affiliated to the Southern

\footnotetext{
${ }^{21}$ Tom Hoogervorst (personal communication, 19-7-2020) adds that Old Javanese has the boat
} name sambong; but that, if at all related, the word-final /ng/ remains unaccounted for. 
Bantu Makhuwa group, its lexicon has been heavily influenced by a southern Swahili dialect (Schadeberg and Mucanheia 2000: 5-8). Koti kalawa, like Mwani ngalawa (SIL Mozambique 2010: 95), does not refer to outrigger canoes, but to other kinds of boat without outriggers. This is also the case in the many non-Sabaki languages in eastern and southern Africa which have borrowed a version of this word from Swahili. Consider, for example, Shona ngàràvá 9/10, "ship" (M. Hannan 1984: 452) - a South Bantu language spoken mainly in Zimbabwe, some distance from the Indian Ocean and even farther from the nearest Swahili-speaking community. ${ }^{22}$ A. Bulkens (1997: 5) gives other examples, including yingalava 9/10, "sail-boat", in the Tswa (Xitswa) language of southern Mozambique, which has added its own prefix to the loanword, leaving the original prefix fossilized. The same seems to have happened in Mwiini, the northernmost Swahili dialect, which has chingalaawa 7/8 (plural zingalaawa), as transcribed by Kisseberth and Abasheikh (2004: 306).

Given the Austronesian associations of outrigger technology, it has been suggested that the name ngalawa comes from the same source. Blench (1996: 431) claimed an origin in Malay galagala, but this seems to be a mistake, subsequently repeated by others. Compare Malay gala gəgala gala-gala "a mixture of pitch and resin used for caulking boats" (A.M. Stevens and A.E. Schmidgall-Tellings 2010: 288, 303). This is a word of Sanskrit origin which is widespread in Southeast Asian and Indian languages (Yule and Burnell 1903: 361-363; Manguin 2012: 602, 620). There is no evidence, however, for this becoming a name for outriggers and a link with ngalawa is unlikely on more than semantic grounds. Allibert (2008: 11) refers to an Oceanic name for outrigger canoes, gala-gala, but I am unable to find further information on this, and it seems an unlikely connection anyway, as is his suggestion that this was part of a separate northern pathway of outrigger diffusion around the Indian Ocean rim which included Sinhalese kollæ̋va, "outrigger", of Sri Lanka and the galbat of Gujarat. ${ }^{23}$

The west Indian gallevat (variously spelt) was not an outrigger, but "a kind of galley, or war-boat with oars, of small draught of water, which continued to be employed on the west coast of India down to the latter half of the 18th century" (Yule and Burnell 1903: 361). Sacleux (1939: 678) thought that Swahili ngalawa ngarawa had been borrowed from India and the Marathi version of this term, probably together with outrigger canoes themselves. Bulkens (1997: 5) accepted this, arguing that the name only came to lose its specific meaning when it spread down the coast of Africa and into the interior. Prins (1959: 208) rejected this etymology on the grounds that the boats are very different and there was no evidence to indicate that the Anglo-Indian word was anything other than a loanword from Portuguese galliot. Instead he proposed derivation from a Swahili verb: "The term ngalawa presumably derives from

\footnotetext{
${ }^{22}$ In his dictionary entry, Hannan wondered whether the source of ngarava might be Portuguese navio, "ship".

${ }^{23}$ This is quite different from Waruno Mahdi's (1999a, 2016, 2017) developed argument about Austronesian and earlier influences on boat forms in the northern Indian Ocean.
} 
gaa-gaa, gara-gara or gala-gala - to roll (of a ship)" (1939: 206). This is no more satisfactory than the first proposal examined above; and why would a boat be named after the very effect that its construction was designed to prevent?

Prins was wrong to dismiss the possibility that gallevat might have a pedigree predating Portuguese influence. As Yule and Burnell (1903: 362) noted, there are similar boat names which are much older. The oldest of these is the Red Sea jalba (plural jilāb or jalbāt), a sewn boat seen by Ibn Jubayr at the Red Sea port of 'Aydhab in 1183 and possibly linked to Farsi galbat or AngloIndian gallevat, despite the very different description of the latter (Agius 2002: 93-96, 2008: 163). This might be relevant to the Swahili case, although the presence of intervocalic/1/in Swahili attestations (sometimes strengthened to / $\mathrm{r} /$ ) suggests that ngalawa is a relatively late borrowing, perhaps from one of the recorded variants without final / $t$ /. It could have first entered Swahili as galawa 5/6, a form which is known in the Mvita dialect (Krapf 1882: 277; Binns 1925: 44; Burt 1910: 201).

The prefixed noun is also found in Comorian, where Maore ngalawa 9/10 describes single outrigger canoes (Allibert 1977: 234) and Ndzuani ngawá 9/10 (Ahmed-Chamanga 1992: 163) has been around long enough to lose *1. While more than one transfer of the word between coastal languages and dialects cannot be ruled out, there are no grounds for assuming, as Sacleux and Bulkens have done, that it was originally borrowed as a name for double outrigger canoes. It is quite possible that it was introduced with something more like the general meaning which it still has on the coast of Mozambique and was only later applied to boats with outriggers. In any event, ngalawa is a difficult word to track over time or reliably link to the history of double outriggers in the region. In order to do this, we must turn to the vocabulary of the outriggers themselves.

There are three main components of double outriggers on the East African coast and islands: the outrigger boom, a connecting piece or peg, and the outrigger float. I shall examine each in turn, beginning with Swahili names for the boom and working outwards towards the floats. Table 3 summarizes the etymologies of all the Swahili terms of which I am aware and are discussed in greater detail below.

\section{Outrigger component}

Dialect - name of component - noun class pairing - short definition

\section{Etymology}

(P)SW $=($ Proto- $)$ Swahili, ND = northern dialects, $\mathrm{SD}=$ southern dialects, $\mathrm{PSA}=$ Proto-Sabaki, $\mathrm{PB}=$ Proto-Bantu, BLR3 = Bantu Lexical Reconstructions 3 (Bastin and Schadeberg 2005), PWMP = ProtoWest-Malayo-Polynesian, ACD = Austronesian Comparative Dictionary (R. Blust and S. Trussell 2016) 
Amu, Mvita rubi [5/6];

Mrima/Tanga, Mgao/Kilwa

Kivinje ndubi [9/10] “outrigger connective"

Bajuni iguu guu 5/6 "outrigger boom" (also "leg")

Malindi mguu 3/4 "outrigger connective" (also "leg")

Amu, Mvita, parapi, Malindi parapi parapai, Mrima/Tanga perapi $9 / 10$ "outrigger float"
(P)SW loanword? ?< Comorian/Ngazidja ndubi ndrubi [9/10] "outrigger float". Compare Malay rubing, "temporary top-strake in a Malay sailing ship" (Stevens and Schmidgall-Tellings 2010: 842), assuming loss of final / $\mathrm{y} /$.

ND semantic extension < Bajuni iguu guu 5/6 "leg" < PSA* igulu 5/6 "leg" < PSA *kugulu 15/6 < PB *-gùdù 15/6 "leg; hind leg" (BLR3 1490). This term is especially used in the plural, hence the phrase maguu ya ngarawa, "outrigger booms", literally "outrigger canoe legs".

ND semantic extension < SW mguu 3/4 "leg" < PSA *kugulu 15/6 < PB *-gùdù 15/6 "leg; hind leg" (BLR3 1490). See also Malindi kamba ya miguu 9/10 "rope lashing, joining the outrigger boom to the connective", literally "cord of the legs (connective)" < SW kamba 9/10 "cord, rope, properly of twisted coir" < Arabic kanbār "coir" + ya 9/10 possessive + mguu 3/4 "leg".

ND lexical innovation, possibly a loanword. Compare Malagasy farafatse "Givotia madagascariensis, tree used by Vezo in making dugouts" (R. Astuti 1995: 18-19; Dahl 1991: 99) < PWMP *paRatpat "a tree of the mangrove swamp: Sonneratia sp." (ACD), though the loss of the final consonant in Swahili would have to be explained.

Malindi kitaruma cha parapi $7 / 8$ "knee strengthening the attachment between the outrigger connective and float", literally "the support of the float"
ND lexical innovation < kitaruma $7 / 8$ diminutive of taruma 5/6 "wooden rib, frame, support" + cha $7 / 8$ possessive + parapi $9 / 10$ "outrigger float": taruma, loanword < Gulf Arabic durmèt, "the sleeping shelf in a boat" < Portuguese dormente "sleeping, dormant" (T.M. Johnstone and J. Muir 1964: 309); parapi (see above). 
Bajuni, Siu ichengu 5/6, Amu mtengo-tengo 3/4 [tengo-tengo] 5/6 utengo-tengo 11/10, Mrima, Unguja rengo 5/6, Mrima/Mtang'ata, Mgao/Kilwa Kivinje mrengu, Pemba mrengo nrengu, Kae/Makunduchi mlengo mrengu 3/4, Mafia/Ngome rengu 5/6 "outrigger boom"; Kae/Makunduchi tengu 5/6 "outrigger float"

Mrima/Mtang'ata, Kae/Makunduchi bao 5/6 "outrigger float"

Mrima/Mtang'ata mbera 9/10, Tumbatu muwera 3/4 mbera 9/10, Kae/Makunduchi mbela 9/10 "outrigger connective"

(SD general) tendegu 5/6 "outrigger connective" (also "furniture leg")
? SD semantic innovation. Compare Mrima mtengo 3/4 "funeral bier", Tumbatu tengu 5/6 "leg of bed", from the same root as Unguja -tenga, "separate, set apart". According to Nurse and Hinnebusch (1993), this verb is an irregular doublet of Unguja -chenga "cut, lop (for example, when harvesting grain)" < PSA *-ceng, "cut, sift" < PB -cèng, "sift; strain; clean" (BLR3 546). There are, however, related forms in other East African Bantu languages and it might be borrowed from one of those. The term for outrigger boom has also been transferred between languages and dialects, as shown by the different Makunduchi attestations and by SD forms with stem-initial / $/$ /, probably originating in Comorian/Ngazidja mrengo 3/4, itself derived from SW.

SD semanticextension < SW bao 5/6 augmentative of ubao 11/10 "board, plank" loanword

< Portuguese pau, "wood; stick, beam". Nurse and Hinnebusch (1993: 646) proposed PSA *luWao 11/10 "board" and PSA *iWao 5/6 "plank, large board", but the evidence for this is questionable.

SD loanword ?< Comorian/Ngazidja vera / ßera/ [9/10] "outrigger connective", possibly a lexical innovation ?< Comorian/Ngazidja -vera, /-ßera/, "fold, bend" < PSA *-pet- "fold, bend" (Nurse and Hinnebusch 1993: 604) < PB *-pèt "bend; fold" (BLR3 2482).

SD semantic extension < SW tendegu 5/6 "leg of bed, of furniture", skewed compound of the stems of SW kitanda 7/8 "bed" + mguu 3/4 "leg": kitanda < PSA *ki(n)tanda 7/8 "bedstead, cognate with PSA *-tand(ik)- "spread" (Nurse and Hinnebusch 1993: 608) < PB *-tànd- "spread; extend" (BLR3 2770); mguu < PSA *kugulu 15/6 < PB *-gùdù 15/6 "leg; hind leg" (BLR3 1490). 
Unguja kilete $7 / 8$ "outrigger connective" (also "thole-pin")
SD semantic extension $<\mathrm{SD}$, Mvita kilete $\sim$ kileti 7/8 "thole-pin" < Arabic, as seen in Kuwaiti Arabic klēt "davit" and Jordanian Arabic kliti "oarlock", linked in turn to Greek kleidia "key" (Johnstone and Muir 1964: 319). Compare also Malay kaliti "tholepin, oarlock" (Stevens and Schmidgall-Tellings 2010: 471), probably from the same source.

SD semantic extension < SD wango "wall hook, peg, bracket, lamp holder" = SD kiango 7/8 (ND chango), Mvita, SD mwango 3/4 < root of SW -angika "hang up, suspend" < PSA *-ang- "hang up" < PB *-yáng- "hang up" (BLR3 3226).

SD loanword < Arabic, as seen in Kuwaiti Arabic karwa "knee" < Portuguese curva "curve, bend" (Johnstone and Muir 1964: 318).
Mgao/Kilwa Kivinje karua [9/10?] "knee strengthening the attachment between the outrigger connective and float"

Table 3. Swahili outrigger terms and their etymologies (for further details see main text).

The most widely used term for an outrigger boom is given by the Standard Swahili dictionaries in a southern dialect form, as mrengu 3/4 (plural mirengu) or rengu 5/6 (plural marengu). I have used Sacleux's transcription of names and definitions where possible in Table 3, because he is often the most accurate source and makes phonological and semantic discriminations which others do not. I have ignored the entries in Prins's (1970) dictionary, because they are largely based on Sacleux and also quite muddled in some respects. It is easy to see how such muddles can arise: many writers are imprecise in their use of terms like "outrigger" and they also seem to have missed the finer distinctions which are (or were) made in the northern dialects of Swahili.

If my reading of Sacleux's different entries and definitions is correct, then noun class 5 is used to denote the whole length of a boom, from one side of the boat and one float to the other, whereas the class 6 plural is used collectively to refer to both booms, perhaps also together with the four connecting pieces and two floats which they support. Sacleux (1939: 514) made this explicit in an entry for the northern dialect plural from matengo, which he noted as being synonymous with Bajuni and Siu machengu and Amu matengo-tengo. In a separate entry for the singular tengo, he marked it as an "unusual" or little-used word, which it would be if it was used to denote the outrigger apparatus at just one end of the boat, including, by implication, just half a float. By contrast, the class 3/4 and 11/10 forms typically refer in the singular to just one arm or side of the boom, hence the Standard Swahili phrase "siasa za mrengo wa kushoto", "left-wing politics", literally "politics of the left-hand outrigger spar" ("rightwing" if kushoto is replaced with kulia) (TUKI 2001: 217). Standard uses mrengo 
in this context, but its doublet mrengu to describe an outrigger, reflecting the inconsistent quality of the final vowel in dialect attestations.

The existence of these distinctions in the northern dialects is consistent with what can be deduced about the origin and history of this term. It comes from the same root as the Standard Swahili verb -tenga, "separate, set apart", the Mvita equivalent of which has been defined as "to separate, to put on one side, to remove, but not to a distant place" (Binns 1925: 246). According to Nurse and Hinnebusch (1993: 582), Mvita and Amu -tenga (with initial dental / t/) derive regularly from a Proto-Sabaki verb which can be reconstructed as *-ceng-, "cut, sift" (from Proto-Bantu -cèng-, "sift; strain; clean", BLR3 546), as does Unguja -chenga, "cut, lop (for example, when harvesting grain)". At the same time, they mark its Unguja doublet -tenga, with alveolar / $t$ /, as irregular. It is not immediately clear how this situation might have arisen: were the Unguja and similar southern dialect forms of this verb (Sacleux 1939: 507, 590) borrowed from northern Swahili? Related nouns can be found in different parts of East Africa, for example, Sangu ishitengo, 7/8, "three-legged wooden stool" (Walsh 1985: 96), an item of local furniture which ensures that sitters are set apart from the ground. Swahili dialect examples with analogous meanings include Mvita and Mrima mtengo 3/4, "a bier used in funerals" (Krapf 1882: 254) and Tumbatu tengu 5/6, "the leg of a bed" (BAKIZA 2012b: 118). Swahili "outrigger boom" fits into the same semantic pattern. The Amu and Mvita terms, however, lack dental /t $/$ and so are irregular like the Unguja verb. This raises the possibility that the northern dialect forms were borrowed from Unguja or another southern dialect.

The southern dialect forms with stem-initial / r/ must also be borrowed. The only candidates are Comorian or one of two Swahili dialects, Chifundi or Vumba. These neighbouring dialects both have / $r$ / instead of inherited * $t$, the intermediate result of a process of lenition undergone by Mijikenda which they have retained, both dialects being the outcome of language shift from that language into Swahili (Nurse and Walsh 1992: 192-196). Comorian has shared in the same process and its dialects also have /r/ in place of *t. Given other borrowing from Comorian discussed below, it is most likely that one of its dialects was the source. This might have been Ngazidja, in which Sacleux (1979: 358) recorded mrengo $3 / 4$ as an alternative to the more widespread Comorian term gend(r)o 5/6 and its variants. ${ }^{24}$ This does not mean that earlier *mtengo must have been inherited: it most likely originally came from a northern Swahili dialect, perhaps via Unguja. There has clearly been a lot of borrowing of the term for "outrigger boom" along the Swahili-speaking coast. The Makunduchi dialect has therefore ended up with three different versions of the same word, one of which, tengu 5/6, refers to the outrigger float rather than the boom (BAKIZA 2012c: 83, 85, 120). There are various ways in which this might have come about: my working hypothesis is that tengu is the older loanword, which was then literally pushed out by mrengu 3/4, which now shares the boom with more recent mlengo $3 / 4$.

${ }^{24}$ Allibert (1977: 234) was given the irregular Maore form mringo at Tsingoni on Mayotte. 
Local patterns of borrowing like this can make it difficult to discern the exact origin of a word and this term is a good example. It is a consequence of the mobility and seasonal movements of fishermen with versatile boats like double outrigger canoes, and can be seen in the convoluted genealogies of some Swahili nautical terms. At the same time, there is no need to resort to speculation about long-distance borrowing to explain many of them. R. Dick-Read's (2005: 92-93) assertion that Swahili tengo is "essentially the same word as the Makassarese tenko for the connecting piece between the outrigger pole and the float" and that this in turn is etymologically connected to baratang, the term for the boom, has already been criticized by Hoogervorst (2013: 96, 2015: 553) as unconvincing. ${ }^{25}$ Prins's (1959: 207) suggestion that the Swahili "word for booms [...] can, perhaps, be connected with the verb kerenga (see kurengwa na maji, to be driven off course by currents[)]", fares no better than his suggestion for the etymology of ngalawa, and not only because there is no active form of -rengwa in the dictionaries. ${ }^{26}$ As we have seen, stem-initial $/ \mathrm{r} /\left(\right.$ and $/ 1 /$ ) in different dialect attestations must derive from earlier ${ }^{*} \mathrm{t}$.

I have only found one term in the literature for the strut inside the hull to which an outrigger boom is lashed. Morgan (1940: 29-30) recorded this as wango in Kilwa Kivinje, also the name for a cross-strut in the prow. Sacleux (1939: 133, 344, 642, 1017) recorded Mrima wango (again, without giving the plural) as equivalent to kiango $7 / 8$, "wall peg used as a coat hanger", a word (also pronounced kiwango) with the more specific meaning of "lamp holder" in other southern dialects, cognate with northern dialect chango $7 / 8$. Southern dialect and Mvita mwango 3/4 has a similar range of meanings, likewise the Bajuni equivalent, mwangiko 3/4. As Sacleux (1939: 67) recognized, these are all related to the Swahili verb -angika, "hang up, suspend". This in turn is a reflex of Proto-Sabaki *-ang-, "hang up" (Nurse and Hinnebusch 1993: 580) and Proto-Bantu *-yáng- "hang up" (BLR3 3226). The term given by Morgan for struts in an outrigger canoe, wango (11/10?), evidently represents a straightforward extension of meaning.

The Swahili names for the connecting pieces of outriggers - the pegs that link the booms and the floats - are perhaps less well known. Two of them are words with other technical meanings which are also used specifically to refer to the pegs. According to Sacleux (1939:375), kileti $7 / 8$ (plural vileti) is a southern dialect and Mvita term for a thole-pin (acting as the fulcrum for an oar) and, separately, a small lever which is used in rope-making to twist the fibres around. According to Prins (1970: 16), in Unguja kilete 7/ 8 (plural vilete) describes both a thole-pin and the connecting strut of an outrigger; Hatchell (1961: 212) also gives it as the term for an outrigger strut in Zanzibar. In the Tumbatu dialect dictionary (BAKIZA 2012b: 53), it is given the second of these

\footnotetext{
${ }^{25}$ Hoogervorst (2013: 96) characterized Dick-Read's "tenko" as "a somewhat obscure term for 'outrigger connective piece' documented in a single language of South Sulawesi (to wit: Makasar (Konjo dial.) tengko)". He has since also found it in some dialects of Bugis and Sama-Bajau, but still thinks the etymology is false (personal communication, 19-7-2020).

${ }^{26}$ Prins's "kerenga" must be a typo for kurenga, an infinitive with a completely different meaning, unconnected to the passive verb kurengwa.
} 
meanings. This is a relatively recent loanword (retaining intervocalic /1/) from Arabic: hence Kuwaiti Arabic klèt (plural klētāt), "davit", and Jordanian Arabic kliti, "oarlock", which has been linked to Greek kleidia, "key" (Johnstone and Muir 1964: 319). It can also be compared to Malay kaliti "tholepin, oarlock" (Stevens and Schmidgall-Tellings 2010: 471), probably from the same source. The extension of meaning from thole-pin to outrigger connective is understandable in terms of their analogous fulcrum-like functions; likewise, the lever used in rope-making.

Sacleux (1939: 884) also recorded tendegu 5/6 (plural matendegu) as a southern dialect term for the connecting pieces. This word and its cognates is the common Swahili name for a furniture leg, such as the leg of a bed: the second element of the compound is contracted from the root of the word for a human or animal leg, mguu 3/4 (plural miguu) in southern and Standard Swahili, guu 5/6 (plural maguu) in Mvita and Amu (Sacleux 1939: 258). Indeed, $m g u u$ itself has been documented as the word for connecting piece in Malindi, on the Kenya coast between Mombasa and Lamu, while the rope lashing is referred to as kamba ya miguu, literally "the cord of the legs" (Haddon 1918: 51). Again, the extension in meaning from a leg to an outrigger connective is quite natural, especially when both are similarly shaped pieces of wood. Common Swahili kamba is a loanword; Nurse and Hinnebusch $(1993: 295,316)$ reconstructed post-Proto-Sabaki *nkamba 9/10 "rope" as a possible early loan from Farsi kanaba "raw thread" (Steingass 1892: 1053), but a derivation from (obsolete) Arabic kanbār "coir" is much more likely (Hoogervorst 2013: 52).

Another southern dialect term for outrigger connecting pieces is Mrima mbera 9/10 and its variants, as shown in Table 3. Sacleux did not record this word and, although it found its way into the Standard Swahili-Swahili dictionary (TUKI 1981: 158), it was mistranslated as "outrigger" in the later Swahili-English volume (TUKI 2001: 191). Although he did not mention the Comorian versions of this word, Ngazidja vera 9/10 (Sacleux 1979: 358) and Maore/Tsingoni shivera 7/8 (Allibert 1977: 234) - he was probably unaware of them - Prins (1959: 207) suggested a derivation from the Ngazidja (Comorian) verb -vera (/-ßera/), "fold, bend". This is indeed cognate with Swahili -peta; both derive from Proto-Sabaki *-pet- with the same meaning (Nurse and Hinnebusch 1993: 604), and ultimately Proto-Bantu *-pèt- (BLR3 2482). Prins's etymology is plausible, given that the connecting pieces of double outrigger canoes in the western Comoros and on the East African coast connect the boom and float at an angle, unlike the vertical connectives of single outriggers in the eastern Comoros and Madagascar. This would make the name of the connecting piece a lexical innovation in western Comorian which accompanied the technological innovation, following which both were adopted into southern Swahili.

There is yet another word for outrigger connectives which is found in both northern and southern Swahili, as well as in Comorian, where it has a different meaning. Table 3 shows the different recorded attestations of this word, which occurs as ndubi 9/10 in the southern dialects of Swahili. As Hatchell (1961: 212) 
noted, the same word (ndubi ndrubi, /ndrubi/) means "outrigger float" in Comorian, at least in the Ngazidja dialect. Prins (1970: 33) assigned northern Swahili dialect rubi to the same 9/10 noun class pairing, whereas 5/6 would be expected for this prefix-less form, which might then be interpreted as an augmentative. The occurrence of different versions of this term in both northern and southern dialects suggests that it might be a Proto-Swahili or early Swahili innovation, although borrowing between dialects cannot be ruled out. Its presence in Ngazidja might be a result of borrowing from Swahili, given the known historical use and influence of the latter language on Grande Comore. A transfer from Comorian to Swahili is also a possibility and would be consistent with Prins's theory (1959: 208) that double outrigger canoes were introduced to the East African coast from the Comoros.

Prins (1979: 33) marked rubi as "unusual", without saying why he thought so. He might have been referring to the presence of intervocalic /b/, which marks this out as a possible loanword. The presence of stem-initial / r/ can also indicate borrowing, although not necessarily: while inherited * 1 is generally lost, there are exceptions to this, and [r] can appear as an allophonic variant of [1]. There is no obvious Swahili etymology for rubi (and ndubi) and Prins did not suggest one. One possible source is Malay rubing, "temporary topstrake in a Malay sailing ship" (Stevens and Schmidgall-Tellings 2010: 842), assuming loss of the final velar nasal. ${ }^{27}$ It also requires a semantic shift, the most likely perhaps being a change in denotation from a plank used to increase the freeboard to a plank being used as a float. This might seem to increase the likelihood of initial borrowing by Comorian, but the change to meaning "outrigger connective" could have been a later development in Swahili. This might have been motivated, as Prins argued, by the adoption of a different word to refer to planks in general and floats specifically, as discussed below. It may or may not be relevant that we already have good evidence for the presence of Malay loanwords in Comorian (Adelaar 2007: 13-15), but not in northern Swahili. Either way, in the absence of stronger linguistic evidence, the identification of this term as a Malay loanword should be considered no more than speculative at present.

Bao 5/6 (plural mabao) is Standard Swahili for a large board or plank, also used for boards with specific purposes, such as mancala and other game boards and the boards used by diviners (Johnson 1939: 28; Sacleux 1939: 93-94; TUKI 1981: 15, 2001: 22). It is the augmentative of ubao 11/10 (plural mbao), which is used to describe planks more generally. As might be expected, both bao and ubao have a variety of nautical uses, referring to strakes and boards of different kinds (A.S. Nabhany 1979: 90; Prins 1970: 3). They are employed similarly in different dialects: the Tumbatu dictionary (BAKIZA 2012b: 124), for example, has ubaowamaliki 11/10, "the first plank on either side of the bottom

\footnotetext{
${ }^{27}$ Note that Swahili and Comorian usually retain final consonants in loanwords and add a final vowel. This is the general rule with words borrowed from Arabic, Persian and different European languages. While there are exceptions, this suggests that loss of final consonants is perhaps more likely to derive from the source or an intermediary language.
} 
of a boat", where Prins (1970: 22) defines the unelided phrase, ubao wa maliki, as "Each of the six planks, three on each side of the keel". The Comorian dialects have the same words, also with nautical applications, such as Maore bao la laka, "bench on a single outrigger canoe" (Blanchy 1996: 38). The extension of the augmentative to describe the floats of double outriggers in Ngazija and some southern Swahili dialects is not surprising, given the flat, plank-like form of the East African floats. Sacleux (1939: 94, 925) recognized Swahili -bao as a borrowing of Portuguese pau, "wood; stick, beam" and Comorian lexicographers have followed suit (Ahmed-Chamanga 1992: 56; Blanchy 1996: 38). Nurse and Hinnebusch (1993: 646), however, proposed Proto-Sabaki "luWao 11/10, "board" and "iWao 5/6, "plank, large board", on the basis of some unlikely semantic shifts and more irregular than regular reflexes. A Portuguese origin is much more plausible and indicates that the use of this word for outrigger floats is a historically recent development. It is possible that it spread from western Comorian and Ngazidja to southern Swahili like other terms, but there is no way of knowing this on present evidence, and it could have been transferred in the other direction.

A different term for outrigger floats has been recorded in the northern dialects of Swahili as parapi 9/10 (see Table 3). This is the noun class pairing given by Prins but not confirmed by other sources: the appearance of this term in the modern Standard Swahili dictionaries (TUKI 1981, 2001) is probably based on Prins's A Swahili Nautical dictionary (1970), which was published by the same research institute in the University of Dar es Salaam. In this dictionary, Prins did not repeat his earlier (1959) record of the variant parapai in Malindi, so it may be that he later considered it to be mistaken. Likewise, Hatchell's (1961: 212) record of perapi in Tanga might also have been mistranscribed. If not, it could have been an informant's misremembered version of the northern term. Hatchell's statement that "The name perapi is known but seldom used" can be taken to imply that this was not a local term, but a word that fishermen knew because of their interactions along the coast - although this is not the only possible interpretation. In the absence of other evidence, however, it can be assumed that parapi is (or was) primarily a northern dialect term.

Haddon's (1918: 49) record of parapi in the Amu dialect was collected by the linguist Alice Werner from an informant in Lamu. He noted, "Miss Werner adds that parapi does not strike her as being a Ki-Swahili word", without saying what this feeling might have been based on. My guess is that she was most struck by the lack of the usual $9 / 10 / \mathrm{Nc}-/$ prefix - if this is indeed its noun class designation - and/or the presence of intervocalic $/ \mathrm{r} /$. Haddon's information from Malindi was collected in 1914 by a District Commissioner, H.R. Montgomery. It is not clear from the text of Haddon's paper whether he or Montgomery wrote the following: "The names given above are the local names, in most cases in Ki-Swahili, but the terms mirengo, parapi, and cheléko are said to have been brought from the Comoro Islands" (1918: 52). We have already discussed the outrigger boom, mrengo 3/4. The cheleko was described by Montomery (in Haddon 1918: 51) as "a long triangular fore-wash-strake" 
which is nailed on to the bow of an outrigger canoe. Prins (1970: 5) defined cheleko $9 / 10$ as both " 1 . upper part of prow in a ngalawa", querying whether this is a Mrima dialect term, and "2. (A[mu]) mast step, used instead of mstamu". However, I can find neither this word nor parapi in the Comorian dictionaries, which, it must be said, are lacking in nautical detail.

Discussing Indonesian and Oceanic outrigger terminologies, Haddon (1918: 53) had his own suggestion: "The term parapi is probably a variant of bără; it cannot be of any of the other terms known to me" - bără being the then recorded name for a float at Buli in Halmahera Island in the Moluccas. As Tom Hoogervorst notes (personal communication, 19-7-2020), this is another example of an isolated Indonesian language which probably played no part in Indian Ocean networks. Haddon (1918: 53-54) later added a further idea put forward by his colleague the linguist Sidney Herbert Ray: "The word prahu (and its variants), for a boat or canoe, occurs all over Indonesia, and as far east as New Britain, where it appears as parau. Ray suggests to me that bara and parapi may be the same word, in which case the term for a canoe has been applied to a float". Both Haddon and Ray, however, were making random connections and drawing unlikely conclusions. It is relatively easy to find words in different languages in the wider Indian Ocean region which resemble one another, but it is much more difficult to demonstrate a connection.

If we assume that Haddon (or Montgomery) was right about the Comorian origin of parapi, and no local etymology can be found, then an Austronesian source becomes a possibility. Looking specifically at words for outrigger floats, for example, Buginese pallawai, "outrigger [float] of a lepa-lepa [flat-bottomed canoe], made of bamboo, on port side, connected by barateng [baratong, boom] to hull" (G. Ammarell 1990: 1190; Hoogervorst 2013: 95; Horridge 1985: 88) is one option, although this and a related Makassarese (Bantaeng dialect) word fit best with the doubtful form parapai, and the change from /l/ to /r/ would still have to be explained. This might be done by adducing strengthening, but this usually occurs in Mrima and other southern dialects, not in the northern dialects. This is therefore probably a chance resemblance, as is, for similar reasons, any connection with Malay polampung "a float for a net/line [...] float, buoy" (Stevens and Schmidgall-Tellings 2010: 553).

A better candidate, perhaps, given that we know it has already crossed the Indian Ocean, might be an earlier form or cognate of Malagasy farafatse, the name of a tree, Givotia madagascariensis Baill., which is much sought after by the Vezo of western Madagascar for making dugout canoes, with and without outriggers (Astuti 1995: 18-19; Dahl 1991: 99). Compare, for example, Malay pərəpat, "tall mangrove-swamp tree, Sonneratia alba Smith, [Combretocarpus] rotundatus [(Miq.) Danser], whose wood is used for making ribs for boats" (Stevens and Schmidgall-Tellings 2010: 738). Could one of these or a related reflex of Proto-West-Malayo-Polynesian * paRatpat (ACD) ${ }^{28}$ have lost its final consonant and shifted in meaning to become northern Swahili parapi or a Comorian intermediary? Without additional supporting evidence, it is difficult to weigh

${ }^{28} \mathrm{ACD}=$ Austronesian Comparative Dictionary (Blust and Trussell 2016). 
this against other possibilities, including potential non-Austronesian sources. Until such evidence emerges, the origin of parapi will remain unresolved.

In Malindi parapi was also recorded in a phrase describing additional wooden supports joining the connecting piece and the float: "The lower end of the mguu [connective] passes through the float, and is rendered more secure by two "knees" or L-shaped pieces of wood (kitaruma cha parapi) nailed to the mguu and the upper surface of the float: this is the general attachment here" (Haddon 1918: 51-52). The first word in this descriptive name, kitaruma 7/8 (plural vitaruma), is the diminutive of taruma 5/6 (plural mataruma), the term for a larger piece nailed inside the hull, defined by Johnson (1939: 455) as "any piece of wood used to stiffen or strengthen a structure or framework", and by Prins (1970: 36) as a "rib, frame, including filling-timbers and square-body frames". Both Johnson (1939: 71, 455) and Sacleux (1939: 872-873) suspected that taruma was from the same Arabic source as darumeti 9/10, "inside woodwork of native vessel, joists carrying the deck, cross-beams, \&c". This is seen, for example, in Kuwaiti Arabic durmēt, "the sleeping shelf, viz. the extra stringer below and contiguous with the deckshelf on which the deck-beams rest", which is derived in turn from Portuguese dormente, "sleeping, dormant" (Johnstone and Muir 1964: 309).

At Kilwa Kivinje, in the southern Swahili dialect, Morgan (1940: 28, 30) reported that the "elbow struts" used to strengthen the attachment between the connective and the floats were called karua (9/10?), a word which I have not found in other Swahili sources. However, it must be the same as Kuwaiti Arabic karwa, (plural karwit), "knee", which Johnstone and Muir (1964: 318) further explicate by telling us that, "The term applies only to lodging and hanging knees. From the Portuguese curva ["curve, bend"] from which the same term is borrowed into Urdu". Vosmer (2017: 206) gives the Arabic as kawra, "a word denoting a curved knee on a vessel", with the same Portuguese etymology. It is a nice coincidence that two different northern and southern dialect terms for these supporting knees should have come from Portuguese via Arabic. It is an indication of the considerable influence the Portuguese had on nautical technology and terminology in the Indian Ocean, as well as the subsequent influence that Arabic had on Swahili.

\section{INDIGENOUS INNOVATION AND EXTERNAL INFLUENCES}

What does this linguistic analysis tell us about the early history of Swahili nautical technology and the different influences upon it? Whatever knowledge the Northeast Coast Bantu and Sabaki-speaking ancestors of the Swahili might have had of watercraft, their modern-day descendants have only retained a single generic term for boats from the pre-Swahili period: reflexes of ProtoSabaki *kyombo 7/8. Like Standard Swahili chombo and its cognates, this must have referred to vessels and utensils of different kinds, not just boats, and so adds little to our knowledge. We know that Eastern Bantu speakers were familiar with at least simple dugout canoes and can guess from the Periplus and other documentary sources that some of them encountered more sophisticated craft, 
including sewn boats, when they settled on the East African coast and began to travel across to the offshore islands. The speakers of Proto-Sabaki also seem to have been familiar with coastal environments. It is entirely possible that other names for watercraft were replaced or lost - or are simply waiting to be recorded or correctly analysed.

As we have seen, Proto-Swahili was marked by two lexical innovations: a new word for dugout canoes, *mutumbwi 3/4, and a term for sewn boats, *idalu 5/6. The motivation behind the first of these innovations is unclear: did it describe a new kind of dugout, perhaps composite or with a sail - or was it simply a local nickname or euphemism which gained traction? The etymology of *idalu and its derivation from the name of a kind of water-bailer made of strips of doum palm leaf, *ndalu 9/10, adds weight to the hypothesis that the original of the modern Swahili dau was indeed a sewn boat, most likely with the kind of square matting sail, *itanga 5/6, which was much later associated with the last Swahili sewn boats to survive, the mtepe and the dau la mtepe. The name alone does not tell us whether or how the first Swahili * madalu (plural) differed from other sewn boats in the western Indian Ocean, and what influences there might have been on its construction. The persistence of the name and number of named varieties suggest that it was both versatile and eminently adaptable (Walsh 2020). We also know this from the construction of modern madau and their incorporation of newer technologies from the Persian Gulf and elsewhere, including the historical switch to nail-built forms and adoption of the lateen sail.

The Bajuni or northern Swahili * mutepe 3/4 was not the ancient boat which it is sometimes assumed to be, though it no doubt included some much older design features. The etymological connection of its name to the petioles and possibly other parts of the coconut palm suggest that it was named after some feature of its construction. Again, the lexical evidence points to local innovation rather than external influence, although the latter cannot be ruled out. The same applies to all but one of the local dialect names for canoes which I have examined - kigusa, kiperea, mbirimiti, mjoo, and muchoro/nchoo - none of which reconstructs to Proto-Swahili. The only borrowed name in this group is that of the hori, almost certainly a late introduction from the north rather than the early loanword which Nurse and Hinnebusch thought. Contrary to my own earlier suggestion of an Austronesian source, the dialect term for a raft - sapa, shapa, and variants - might also be a Swahili innovation, although the evidence for this as well as its antiquity is inconclusive. The only boat name that can be convincingly identified as Austronesian in origin is the generic poetic term sambo $\sim$ sambu $9 / 10$. There is no evidence, however, to indicate that this is anything other than a relatively recent loanword from Malagasy.

Perhaps surprisingly, given the image which is often painted of outriggers canoes as ancient Austronesian introductions, their widespread Swahili name, ngalawa 9/10 and variants, seems to be a relatively recent loanword from the north rather than the east. As we have seen, its most likely source was one of the series of related terms found in languages spoken around the Arabian Sea (compare Anglo-Indian gallevat). The linguistic evidence suggests that it was 
initially borrowed as a name for boats without outriggers, and only subsequently repurposed. The hypothesis of a relatively late introduction and spread is supported by the lack of early documentary references to the ngalawa by name (Prins 1959: 209). It also recalls Pierre-Yves Manguin's observation (2016: 63) that, although there is little doubt that Austronesian language speakers introduced outrigger technologies to the western Indian Ocean, this "does not necessarily carry the corollary that they actually sailed in these small vessels across the Indian Ocean or along its shores, all the way to and from Madagascar". While it is possible that outrigger canoes had a longer history on the Swahili-speaking coast under another name, their presence does not mean that they were introduced directly from Indonesia or even Madagascar, as is sometimes assumed. We know from scattered written references that outrigger canoes were sometimes used in direct raids on the coast and islands, but not that this led to their adoption. ${ }^{29}$

The analysis of outrigger terminologies provides further clues towards understanding what might have happened. Only one term is independently attested in both northern and southern dialects and so might be reconstructed to early Swahili: *ndubi 9/10 "outrigger connective", and its (presumed) augmentative, ${ }^{*}(i)$ rubi $5 / 6$. However, although we can propose that this was an early innovation in Swahili, its modern distribution might equally be accounted for by inter-dialectal borrowing. As we have seen, the source of this apparent innovation is, also unclear. It has the phonological characteristics of a loanword, but was it borrowed from Comorian, or vice-versa? And is a derivation from Malay rubing, "temporary top-strake" plausible?

None of the other outrigger terms recorded can be reconstructed to ProtoSwahili. Taken together with the uncertainty surrounding the reconstruction of the previous item, this suggests that double outriggers were indeed only introduced after the break-up of the early Swahili community and the northsouth dialect split; perhaps even some time after this. The existence of different terms with varying distributions for the same outrigger components suggests a dynamic process of innovation and change over time, with different external influences, local adaptations, and criss-crossing patterns of technical and linguistic transfer. In the absence of more comprehensive and detailed records of dialect vocabulary and usage, it is difficult at present to disentangle the available data and provide anything like a certain chronology of development or even the approximation of one.

In addition to rubi/ndubi, there is only one other term which might have an Austronesian source: northern dialect parapi 9/10, "outrigger float". But again, this is speculation with little evidence to back it up. The Comorian origin of the southern dialect term for an outrigger connective, mbera $9 / 10$ and its cognates, provides some support for Prins's theory, already mentioned, that

\footnotetext{
${ }^{29}$ The best documented raids are those undertaken on the Mozambique coast by the Sakalava in the nineteenth century. Interestingly, the traditional history of Kua on Juani Island in the Mafia Archipelago includes a folk memory not only of this era of raiding, but also of the Sakalava name for the single outrigger canoes which were used, laka, remembered as " $r a k a$ " (G.S.P. Freeman-Grenville 1975: 298; the Merina and Standard Malagasy term is lakana).
} 
the double outrigger was introduced from the Comoros. This is also the most likely route for Austronesian lexical influence to have followed. Otherwise, the lexical evidence suggests that the northern and southern dialects of Swahili were subject to different influences at different times, and probably separate episodes of introduction and adaptation, as well as cross-learning as outrigger fishermen moved up and down the coast to their seasonal fishing grounds and in search of other opportunities.

The lexical impacts of this dynamic process can be further illustrated by a comparison of outrigger taxonomies, the local sets of terms recorded in different ethnographic and linguistic sources. Table 4 shows four different Swahili taxonomies from both northern and southern dialects. I have also added in the only complete set which I have for a Comorian dialect, plus cognate terms from Sakalava and Vezo, two dialects of Malagasy, spoken in the northwest and west of Madagascar. It is striking that there is no relation at all between the Malagasy terms, which probably have Austronesian roots, and those from Mayotte and the Comorian dialect Maore. While there is some overlap between the latter and the Swahili taxonomies, they are all different. If other dialects and local varieties of Swahili were added to this table, the number of different taxonomies would no doubt increase, given that some of the recorded terms do not appear in this preliminary comparison. It is a pity that more taxonomies like this have not been published: it is not always possible to deduce them from the partial vocabularies provided in dialect dictionaries.

\begin{tabular}{|c|c|}
\hline $\begin{array}{l}\text { Language } \\
\text { (source) }\end{array}$ & Boom \\
\hline
\end{tabular}

\section{Swahili}

Amu

(Haddon 1918: 49)

Malindi

(Haddon 1918: 51)

Kae/Makunduchi (BAKIZA 2012c)

Mgao/Kilwa Kivinje (Morgan 1940: 28-30)

$\begin{array}{lcc}\text { mrengu 3/4 } & \text { rubi }[5 / 6] & \text { parapi }[9 / 10] \\ \text { mrengo 3/4 } & \text { mguu 3/4 } & \text { parapi }[9 / 10] \\ \text { mlengo } \sim \text { mrengu 3/4 } & \text { mbela 9/10 } & \text { tengu } 5 / 6 \\ \text { mrengu 3/4 } & \text { ndubi 9/10 } & \text { bau 5/6 }\end{array}$

\section{Comorian}

Maore/Tsingoni

(Allibert 1977: 243)

mringo $3 / 4$

shivera $7 / 8$

gando $5 / 6$

\section{Malagasy}

Sakalava/Nosy Be

(Binet 1970: 183-184, 187)

Vezo

(Poirot n.d.)

varona tatiky fañary

varoña tatike fañare

Table 4. Comparison of Swahili, Comorian, and Malagasy outrigger taxonomies. 


\section{CONCLUSION}

More systematic collection of nautical vocabulary in different dialects is clearly required if the analysis begun in this paper is to be developed and improved. The available lexical evidence has already allowed us to draw conclusions which challenge received wisdom about the nautical history and maritime adaptations of the Swahili. It provides us with new insights into the history of the Swahili and their remarkable transformation from being a small group of mixed farmers familiar with inland waterways to becoming the possessors of the rich maritime culture which we know today. It highlights the role of indigenous innovation in that process, including the importance of the adoption and adaptation of sewn boats to the spectacular expansion of the early Swahili along the eastern African coast and across to its islands in the two hundred years or so following the emergence of Proto-Swahili sometime in the middle of the first millennium CE. This was a critical period in the development of Swahili maritime culture, which took place some centuries before the transition to the "fully maritime way of life" in the early part of the second millennium which archaeologists and historians have written about (Crowther et al. 2016: 224). Coastal settlement alone might not make a people maritime (Fleisher et al. 2015: 110), but the ability to sail to and found coastal communities more than a thousand miles apart surely did.

Despite the suspicion that other peoples who were sailing and trading in the western Indian Ocean might have had a hand in this process, there is no clear evidence in the nautical vocabulary examined here for their direct or indirect involvement before the break-up of the early Swahili community. This does not rule such external influences out, but it does make it harder to claim that they were the main driver of the developments in nautical technology which facilitated Swahili expansion in the third quarter of the first millennium CE. Double outrigger technology in particular seems not to have been introduced until after the settlement of the Lamu Archipelago and the north-south Swahili dialect split. If the different outrigger terminologies are any guide, possible Malagasy or other Austronesian influence might have come through the Comoros, and it could well have reached the East African coast and islands at different places and times. The lexical evidence is much easier to interpret when it comes to loanwords from the Persian Gulf and around the Arabian Sea: most of this influence seems to date from the second half of the second millennium and the era of European expansion and globalization. This is the period, of course, in which the versatile Swahili dau became the "dhow" of wider renown. It was also the time in which most Arabic loanwords entered Swahili, including the names of the various kinds of larger craft which are now loosely described as dhows. 


\section{REFERENCES}

Adelaar, A. 1994. "Malay and Javanese loanwords in Malagasy, Tagalog, and Siraya (Formosa)", Bijdragen tot de Taal-, Land-en Volkenkunde 150(1): 50-65.

Adelaar, A. 2007. "Language contact in the Austronesian far west". [Paper, The 3rd Conference on Austronesian Languages and Linguistics, School of Oriental and African Studies, University of London, 21-22 September.]

Adelaar, A. 2009. "Loanwords in Malagasy", in: M. Haspelmath and U. Tadmor (eds), Loanwords in the world's languages; A comparative handbook, pp. 717-746. Berlin: De Gruyter Mouton.

Adelaar, A. 2015. "From Borneo to Bantu; How the Malagasy third person genitive pronoun *-ni may have become a locative suffix in Swahili", in: Proceedings of the second international workshop on information structure of Austronesian languages, 25 December 2015, pp. 161-177. ILCAA, TUFS.

Adelaar, A. 2016. "Austronesians in Madagascar; A critical assessment of the works of Paul Ottino and Philippe Beaujard", in: G. Campbell (ed.), Early exchange between Africa and the wider Indian Ocean world, pp. 77-112. Cham: Palgrave Macmillan.

Africa Inland Mission 1970. Kamba-English dictionary. Third edition. Nairobi: The Literacy Centre of Kenya / The Afrolit Association.

Agius, D.A. 2002. In the wake of the dhow; The Arabian Gulf and Oman. Reading: Ithaca Press.

Agius, D.A. 2005. Seafaring in the Arabian Gulfand Oman; The people of the dhow. London: Kegan Paul.

Agius, D.A. 2008. Classic ships of Islam; From Mesopotamia to the Indian Ocean. Leiden/Boston, NY: Brill.

Ahmed-Chamanga, M. 1992. Lexique Comorien (Shindzuani) Français. Paris: Editions l'Harmattan.

Allibert, C. 1977. Histoire de Mayotte, île de l'archipel des Comores, avant 1841. Thèse de doctorat de 3 e cycle d'histoire, Paris I, Sorbonne.

Allibert, C. 1984. Mayotte, plaque tournante et microcosme de l'océan Indien occidental. Paris: Anthropos.

Allibert, C. 2008. "Austronesian migration and the establishment of the Malagasy civilization; Contrasted readings in linguistics, archaeology, genetics, and cultural anthropology", Diogenes 218: 7-16.

Allibert, C. 2012. "Les réseaux de navigation du début de l'ère chrétienne au XVIe siècle. Rencontre de populations, échanges commerciaux et matrimoniaux, concurrence à l'ouest et à l'est de Madagascar", Topoi, Orient-Occident (Supplement) 11: 341-357.

Al-Salimi, A. and E. Staples (eds). 2017. Oman; A maritime history. Hildesheim, Zürich/New York, NY: Georg Olms Verlag.

Ammarell, G. 1990. Entry for palléwai. [Retrieved from: http:/ / sealang.net/ buginese/dictionary.htm; accessed on 30-4-2020.]

Astuti, R. 1995. People of the sea; Identity and descent among the Vezo of Madagascar. Cambridge: Cambridge University Press.

BAKIZA 2012a. Kamusi la lahaja ya Kipemba. Oxford: Oxford University Press. 
BAKIZA 2012b. Kamusi la lahaja ya Kitumbatu. Zanzibar: Baraza la Kiswahili la Zanzibar.

BAKIZA 2012c. Kamusi la lahaja ya Kimakunduchi. Zanzibar: Baraza la Kiswahili la Zanzibar.

Bastin, Y. and T. Schadeberg (eds). 2005. "Bantu lexical reconstructions 3" (BLR3). [Retrieved from: http//ww.africamuseum.be/en/research/ discover/human_sciences/culture_society/blr, accessed on 30-4-2020.]

Beaujard, P. 2018. “The progressive integration of eastern Africa into an AfroEurasian world-system, first-fifteenth centuries CE", in: S. Wynne-Jones and A. LaViolette (eds), The Swahili World, pp. 365-377. Abingdon/New York, NY: Routledge.

Beaujard, P. 2019. The worlds of Indian Ocean; A global history. Vol 2: From the seventh century to fifteenth century CE. Cambridge: Cambridge University Press.

Benson, T.G. (ed.). 1964. Kikuyu-English dictionary. Oxford: Clarendon Press. Binet, D. 1970. "Quelques types de pirogue à Nosy-Be", Taloha 3: 183-191.

Binns, H.K. 1925. Swahili-English dictionary; Being Dr. Krapf's original SwahiliEnglish dictionary revised and re-arranged. London: Society for Promoting Christian Knowledge.

Blanchy, S. 1996. Dictionnaire Mahorais-Français Français-Mahorais. Paris: L'Harmattan.

Blench, R. 1996. "The ethnographic evidence for long-distance contacts between Oceania and East Africa", in: J. Reade (ed.), The Indian Ocean in antiquity, pp. 417-438. London/New York, NY: Kegan Paul International.

Blench, R. 2012. “Two vanished African maritime traditions and a parallel from South America", African Archaeological Review 29: 273-292.

Blust, R. and S. Trussel. 2016. "Austronesian comparative dictionary" (ACD). [Retrieved from: http/ / www.trussel2.com/ACD, accessed on 30-4-2020.]

Boivin, N. and A. Crowther. 2018. "Early connections", in: S. Wynne-Jones and A. LaViolette (eds), The Swahili World, pp. 105-120. Abingdon/New York, NY: Routledge.

Bulkens, A. 1997. "Some nominal stems for 'canoe' in Bantu languages". [Paper, 47th Colloquium on African Languages and Linguistics (CALL 27), University of Leiden, 28-30 August.]

Burkill, I.H. 1935. A dictionary of the economic products of the Malay Peninsula. Two vols. London: Crown Agents for the Colonies.

Burrow, T. and M.B. Emeneau. 1984. A Dravidian etymological dictionary. Second edition. Oxford: Clarendon Press.

Burt, F. 1910. Swahili grammar and vocabulary. London: Society for Promoting Christian Knowledge.

Burton, Richard F. 1872. Zanzibar; City, island, and coast. Two vols. London: Tinsley Brothers.

Casson, L. 1989. The Periplus Maris Erythraei; Text with introduction, translation, and commentary. Princeton, NJ: Princeton University Press. 
Chandra, S. and H.P. Ray (eds). 2013. The sea, identity, and history; From the Bay of Bengal to the South China Sea. New Delhi: Manohar.

Chittick, N. 1980. "Sewn boats in the western Indian Ocean, and a survival in Somalia", The International Journal of Nautical Archaeology and Underwater Exploration 9(4): 297-309.

Crowther, A., P. Faulkner, M.E. Prendergast, E.M. Quintana Morales, M. Horton, E. Wilmsen, A.M. Kotarba-Morely, A. Christie, N. Petek, R. Tibesasa, K. Douka, L. Picornell-Gelabert, X. Carah, and N. Boivin. 2016. "Coastal subsistence, maritime trade, and the colonization of small offshore islands in eastern African prehistory", The Journal of Island and Coastal Archaeology 11(2): 211-237.

Dahl, O.C. 1988. "Bantu substratum in Malagasy”, Études Océan Indien 9: 91132.

Dahl, O.C. 1991. Migration from Kalimantan to Madagascar. Oslo: Norwegian University Press.

Dick-Read, R. 2005. The phantom voyagers; Evidence of Indonesian settlement in Africa in ancient times. Winchester: Thurlton Publishing.

Fischer, F. 1949. Grammaire-dictionnaire comorien. Strasbourg: Société d'Edition de la Basse-Alsace.

Fleisher, J., P. Lane, A. LaViolette, M. Horton, E. Pollard, E. Quintana Morales, T. Vernet, A. Christie, and S. Wynne-Jones. 2015. "When did the Swahili become maritime?", American Anthropologist 117(1): 100-115.

Freeman-Grenville, G.S.P. 1975. The East African coast; Select documents from the first to the earlier nineteenth century. Second edition. London: Rex Collings.

Gilbert, E. 1998. "The mtepe; Regional trade and the late survival of sewn ships in East African waters", The International Journal of Nautical Archaeology 27(1): 43-50.

Gilbert, E. 2004. Dhows and the colonial economy of Zanzibar 1860-1970. Oxford: James Currey.

Gilbert, E. 2018. "Eastern Africa and the dhow trade", in: S. Wynne-Jones and A. LaViolette (eds), The Swahili world, pp. 378-387. Abingdon/New York, NY: Routledge.

Gleiss, F. 1912. "Wörterbuch Schambala-Deutsch und Deutsch-Schambala", in: O. Rösler and F. Gleiss, Schambala-Grammatik mit Übungssätzen nebst einer Sammlung von Redensarten in Gesprächsform und Wörterbuch Schambala-Deutsch und Deutsch-Schambala, pp. 53-134. Berlin: Georg Reimer.

Grottanelli, V.L. 1955. Pescatori dell'Oceano Indiano: Saggio etnologico preliminare sui Bagiuni, Bantu costieri dell'Oltregiuba. Roma: Cremonese.

Gueunier, N.J. 1986. Lexique du dialecte Malgache de Mayotte (Comores). Paris: Institut National des Langues et Civilisations Orientales, Centre Océan Indien Occidental.

Haddon, A.C. 1918. “The outrigger canoe of East Africa”, Man 18: 49-54.

Hannan, M. 1984. Standard Shona dictionary. Revised edition with addendum. Harare: College Press Publishers.

Harries, L. 1952. “Popular verse of the Swahili tradition”, Africa 22(2): 158-164. 
Hatchell, G.W. 1961. "The ngalawa and the mtepe", Tanganyika Notes and Records 57: 210-215.

Heine, B. 1989. "A note on the historical classification of Mvita” , in: M.-F. Rombi (ed.), Le Swahili et ses limites; Ambiguité des notions reçues, pp. 59-62. Paris: Éditions Recherche sur les Civilisations.

Hinnebusch, T.J. 1996. "What kind of language is Swahili?", Afrikanistische Arbeitspapiere 47: 73-95.

Hoogervorst, T. 2013. Southeast Asia in the ancient Indian Ocean world. Oxford: Archaeopress.

Hoogervorst, T. 2015. "An interdisciplinary approach towards the dispersal of Southeast Asian maritime technology across the Indian Ocean", in: S. Tripati (ed.), Maritime contacts of the past; Deciphering connections amongst communities, pp. 532-568. Delhi: G.A. Books.

Hoogervorst, T. 2016. "Tracing maritime connections between Island Southeast Asia and the Indian Ocean world", in: T. Hodos (ed.), The Routledge handbook of archaeology and globalization, pp. 751-767. Abingdon/New York, NY: Routledge.

Hornell, J. 1934. "Indonesian influence on East African culture”, Journal of the Royal Anthropological Institute of Great Britain and Ireland 64: 305-332.

Hornell, J. 1941. "The sea-going mtepe and dáu of the Lamu Archipelago", The Mariner's Mirror 27(1): 54-68.

Hornell, J. 1942. "The sea-going mtepe and dáu of the Lamu Archipelago", Tanganyika Notes and Records 14: 27-37. [Reprint.]

Horridge, A. 1985. The prahu; Traditional sailing boat of Indonesia. Second edition. Singapore: Oxford University Press.

Horridge, A. 1986. Sailing craft of Indonesia. Singapore: Oxford University Press. Ichumbaki, E.B. 2017. "When did the Swahili become maritime? A reply to Jeffrey Fleisher et al. (2015)", in: L. Harris (ed.), Sea ports and sea power; African maritime cultural landscapes, pp. 1-11. New York, NY: Springer.

Jewell, J.H.A. 1969. Dhows at Mombasa. Nairobi: East African Publishing House. Johnson, F. 1939. A Standard Swahili-English dictionary. London: Oxford University Press.

Johnstone, T.M. and J. Muir. 1964. "Some nautical terms in the Kuwaiti dialect of Arabic", Bulletin of the School of Oriental and African Studies 27(2): 299-332.

Jones, A.M. 1964. Africa and Indonesia; The evidence of the xylophone and other musical and cultural factors. Leiden: E.J. Brill.

Jones, D.L. 1995. Palms throughout the world. Washington DC: Smithsonian Institution Press.

Kipacha, A. 2004. “Kingome-English lexicon”, Swahili Forum 11: 179-209.

Kisbey, W.H. 1906. Zigula-English dictionary. London: Society for Promoting Christian Knowledge.

Kisseberth, C.W. and M.I. Abasheikh. 2004. The Chimwiini lexicon exemplified. Tokyo: Research Institute for Languages and Cultures of Asia and Africa (ILCAA), Tokyo University of Foreign Studies.

Krapf, L. 1882. A dictionary of the Suahili language. London: Trubner \& Co. 
Krapf, L. and J. Rebmann. 1887. A Nika-English dictionary. Edited by T.H. Sparshott. London: Society for Promoting Christian Knowledge.

Krumm, B. 1940. Words of oriental origin in Swahili. Second edition. London: The Sheldon Press.

Kusimba, C.M. and J.R. Walz. 2018. “When did the Swahili become maritime? A reply to Fleisher et al. (2015), and to the resurgence of maritime myopia in the archaeology of the East African coast", American Anthropologist 120(3): 429-443.

Lambert, H.E. 1958a. Chi-Jomvu and Ki-Ngare; Sub-dialects of the Mombasa area. Kampala: East African Swahili Committee, Makerere College.

Lambert, H.E. 1958b. Chi-Chifundi: A dialect of the southern Kenya coast. Kampala: East African Swahili Committee, Makerere College.

Lodhi, A.Y. 2000. Oriental Influences in Swahili; A study in language and culture contacts. Göteborg: Acta Universitatis Gothoburgenis.

Lydekker, C.J.W. 1919. “The 'mtepe' dhau of the Bajun islands", Man 19: 88-92.

Mahdi, W. 1994a. "Some Austronesian maverick protoforms with culturehistorical implications-I", Oceanic Linguistics 33(1): 167-229.

Mahdi, W. 1994b. "Some Austronesian maverick protoforms with culturehistorical implications-II", Oceanic Linguistics 33(2): 431-490.

Mahdi, W. 1998. "Linguistic data on the transmission of Southeast Asian cultigens to India and Sri Lanka", in: R. Blench and M. Spriggs (eds), Archaeology and language II; Correlating archaeological and linguistic hypotheses, pp. 390-415. London: Routledge.

Mahdi, W. 1999a. "The dispersal of Austronesian boat forms in the Indian Ocean", in: R. Blench and M. Spriggs (eds), Archaeology and language III; Artefacts, languages and texts, pp. 144-179. London: Routledge.

Mahdi, W. 1999b. "Linguistic and philological data towards a chronology of Austronesian activity in India and Sri Lanka", in: R. Blench and M. Spriggs (eds), Archaeology and language IV; Languages change and cultural transformation, pp. 160-242. London: Routledge.

Mahdi, W. 2007. Malay words and Malay things; Lexical souvenirs from an exotic archipelago in German publications before 1700. Wiesbaden: Harrassowitz Verlag.

Mahdi, W. 2016. "Origins of Southeast Asian shipping and maritime communication across the Indian Ocean", in: G. Campbell (ed.), Early exchange between Africa and the wider Indian Ocean world, pp. 25-49. Cham: Palgrave Macmillan.

Mahdi, W. 2017. "Pre-Austronesian origins of seafaring in Insular Southeast Asia", in: A. Acri, R. Blench, and A. Landmann (eds), Spirits and ships; Cultural transfers in early Monsoon Asia, pp. 325-374. Singapore: ISEAS Publishing.

Manguin, P.-Y. 2000. "Les techniques de construction navale aux Maldives originaires d'Asie du Sud-Est", Techniques E culture 35-36: 21-47.

Manguin, P.-Y. 2012. "Asian ship-building traditions in the Indian Ocean at the dawn of European expansion", in: O. Prakash (ed.), The trading world of the Indian Ocean 1500-1800, pp. 597-629. Delhi: Pearson. 
Manguin, P.-Y. 2016. "Austronesian shipping in the Indian Ocean; From outrigger boats to trading ships", in: G. Campbell (ed.), Early exchange between Africa and the wider Indian Ocean world, pp. 51-76. Cham: Palgrave Macmillan.

Manguin, P.-Y. 2019. "Sewn boats of Southeast Asia; The stitched-plank and lashed-lug tradition", The International Journal of Nautical Archaeology 48(2): 400-415.

Martin, E.B. and C.P. Martin. 1978. Cargoes of the East; The ports, trade, and culture of the Arabian seas and western Indian Ocean. London: Hamish Hamilton.

Molesworth, J.T. 1857. A dictionary, Maráthí and English. Second edition. Bombay: Bombay Education Society's Press.

Morgan, J.C. 1940. "The ngalawa of the Kilwa coast", Tanganyika Notes and Records 9: 27-36.

Mugane, J.M. 2015. The story of Swahili. Athens, OH: Ohio University Press.

Nabhany, A.S. 1979. Sambo ya Kiwandeo; The ship of Lamu-island. Edited by G. Miehe and T.C. Schadeberg. Leiden: Afrika-Studiecentrum.

Nurse, D. 1982. "A tentative classification of the primary dialects of Swahili", Sprache und Geschichte in Afrika 4: 165205.

Nurse, D. 1984/85. "A historical view of the southern dialects of Swahili", Sprache und Geschichte in Afrika 6: 225250.

Nurse, D. 2000. Inheritance, contact, and change in two East African languages. Köln: Rüdiger Köppe Verlag.

Nurse, D. 2019. "When northern Swahili met southern Somali", in: E. Clem, P. Jenks, and H. Sande (eds), Theory and description in African linguistics; Selected papers from the 47th Annual Conference on African Linguistics, pp. 649-665. Berlin: Language Science Press.

Nurse, D. and T.J. Hinnebusch. 1993. Swahili and Sabaki; A linguistic history. Berkeley, CA: University of California Press.

Nurse, D. and T. Spear. 1985. The Swahili; Reconstructing the history and language of an African society, 800-1500. Philadelphia, PA: University of Pennsylvania Press.

Nurse, D. and M. Walsh. 1992. "Chifundi and Vumba; Partial shift, no death", in: M. Brenzinger (ed.), Language death; Factual and theoretical explorations with special reference to East Africa, pp. 181-212. Berlin/New York, NY: Mouton de Gruyter.

Parkin, D. and R. Barnes (eds). 2002. Ships and the development of maritime technology in the Indian Ocean. London: RoutledgeCurzon.

Poirot, G. n.d. “Dictionnaire_Vezo". [Retrieved from: https://beninfongbe. com/VEZO/4_dictionnaire_vezo/plan_dictionnaire_vezo.htm, accessed on 30-4-2020.]

Poumailloux, P. 1999. “Le mtepe, bateau cousu des Swahili, suivi d'un glossaire technique", Études Océan Indien 27-28: 227-328.

Prins, A.H.J. 1959. "Uncertainties in coastal cultural history; The 'ngalawa' and the "mtepe", Tanganyika Notes and Records 53: 204-213.

Prins, A.H.J. 1965. Sailing from Lamu; A study of maritime culture in Islamic East Africa. Assen: Van Gorcum. 
Prins, A.H.J. 1967. The Swahili-speaking peoples of Zanzibar and the East African coast (Arabs, Shirazi, and Swahili). London: International African Institute.

Prins, A.H.J. 1970. A Swahili nautical dictionary. Dar es Salaam: Chuo cha Uchunguzi wa Lugha ya Kiswahili.

Prins, A.H.J. 1982. "The mtepe of Lamu, Mombasa, and the Zanzibar Sea", Paideuma; Mitteilungen zur Kulturkunde 28: 85-100.

Quadros, J. 1938. "Barcos da Índia", Boletim do Instituto Vasco da Gama 38: 136-142.

Ray, D. 2014. Disentangling ethnicity in East Africa, ca. 1-2010 CE; Past communities in present practices. PhD thesis, University of Virginia.

Sacleux, C. 1939. Dictionnaire Swahili-Français. Paris: Institut d'Ethnologie, Université de Paris.

Sacleux, C. 1979. Le dictionnaire Comorien-Français et Français-Comorien du R.P. Sacleux. Two vols., edited by M. Ahmed Chamanga and N.J. Gueunier. Louvain-Paris: Peeters.

Schadeberg, T.C. and F.U. Mucanheia. 2000. Ekoti; The Maka of Swahili language of Angoche. Köln: Rüdiger Köppe Verlag.

Sentance, P.D. 1981. “The mtepe; The origins and longevity of an East African craft", The Great Circle 3(1): 1-9.

Sheriff, A. 2010. Dhow cultures of the Indian Ocean; Cosmopolitanism, commerce, and Islam. London: Hurst \& Company.

Sheriff, A., K.A. Abdalla, and A.I. Mshenga. 2006. “The mtepe 'Shungwaya' sails again", ZIFF Journal 3: 35-44.

SIL Mozambique. 2010. Vocabulário de Kimwani. Nampula: SIL Mozambique.

Steingass, F.J. 1892. A comprehensive Persian-English dictionary. London: Routledge and Kegan Paul.

Stevens, A.M. and A.E. Schmidgall-Tellings. 2010. A comprehensive IndonesianEnglish dictionary. Second edition. Athens: Ohio University Press.

Taylor, W.E. 1891. African aphorisms; Or saws from Swahili-land. London: Society for Promoting Christian Knowledge.

Teubner, J.K. 1974. "Altaisches, fernöstlisches und malaiisches Wortgut im Suaheli", Zeitschrift der Deutschen Morgenländischen Gesellschaft, Supplement II(18): 629-636.

TUKI. 1981. Kamusi ya Kiswahili Sanifu. Dar es Salaam: Oxford University Press.

TUKI. 2001. Kamusi ya Kiswahili-Kiingereza; Swahili-English dictionary. Dar es Salaam: Taasisi ya Uchunguzi wa Kiswahili, Chuo Kikuu cha Dar es Salaam.

Vernet, T. 2015. "East African travelers and traders in the Indian Ocean; Swahili ships, Swahili mobilities ca.1500-1800”, in: M. Pearson (ed.), Trade, circulation, and flow in the Indian Ocean world, pp. 167-202. Basingstoke/ New York, NY: Palgrave Macmillan.

Villiers, A. 2006. Sons of Sindbad; An account of sailing with Arabs in their dhows. Second edition. London: Arabian Publishing.

Voeltzkow, A. 1923. "Witu-Inseln und Zanzibar-Archipel”, in: A. Voeltzkow (ed.), Reise in Ostafrika in den Jahren 1903-1905; Wissenschaftliche 
Ergebnisse; Vol. 1 Part 1, pp. 1-329. Stuttgart: E. Schweizerbart'sche Verlagsbuchhandlung (Erwin Nägele).

Vosmer, T. 2017. "The development of boatbuilding technologies and typologies", in: A. Al-Salimi and E. Staples (eds), Oman; A maritime history, pp. 185-222. Hildesheim, Zürich/New York, NY: Georg Olms Verlag.

Walsh, M. 1985. "Shisango dictionary". [Retrieved from: http//www.scribd. com/doc/14594720/Shisango-Dictionary-draft, accessed on 30-4-2020.]

Walsh, M. 1986. "Chichifundi vocabulary: Mkwiro sub-dialect". [Retrieved from: http//www.scribd.com/doc/13998554/Chichifundi-VocabularyMkwiro-Sub-dialect, accessed on 30-4-2020.]

Walsh, M. 1995. "Eating bats on Pemba island; A local innovation or cultural borrowing? Mvita; Newsletter of the Regional Centre for the Study of Archaeology in Eastern and Southern Africa (Mombasa) 6: 15-18.

Walsh, M. 2017. "Evidence for early Malay and Malagasy loanwords in Swahili". [Presentation, Baraza III: Swahili Conference at SOAS, School of Oriental and African Studies, University of London, 14 October.]

Walsh, M. 2018. "The Swahili language and its early history", in: S. WynneJones and A. LaViolette (eds), The Swahili world, pp. 121-130. Abingdon/ New York, NY: Routledge.

Walsh, M. 2019. "Cockatoos and crocodiles; Searching for words of Austronesian origin in Swahili", Kenya Past and Present 46: 32-40.

Walsh, M. 2020. "Sewn boats of the Swahili coast; The mtepe and the dau reconsidered", Kenya Past and Present 47.

Wehr, H. 1979. A dictionary of modern written Arabic (Arabic-English). Fourth edition, edited by J.M. Cowan. Wiesbaden: Otto Harrassowitz.

Whiteley, W.E. 1958. The dialects and verse of Pemba; An introduction. Kampala: East African Swahili Committee, Makerere College.

Woodward, H.W. 1882. Collections for a handbook of the Boondéi language. London: Society for Promoting Christian Knowledge.

Wynne-Jones, S. and A. LaViolette (eds). 2018. The Swahili world. Abingdon/ New York, NY: Routledge.

Yule, H. and A.C. Burnell. 1903. Hobson-Jobson; A glossary of colloquial AngloIndian words and phrases. Second edition, edited by W. Crooke. London: John Murray. 